\title{
In vivo characterization of metabotropic glutamate receptor type 5 abnormalities in behavioral variant FTD
}

\author{
Antoine Leuzy $\cdot$ Eduardo Rigon Zimmer · Jonathan Dubois $\cdot$ Jens Pruessner \\ Cory Cooperman · Jean-Paul Soucy • Alexey Kostikov • Esther Schirmaccher • \\ René Désautels $\cdot$ Serge Gauthier $\cdot$ Pedro Rosa-Neto
}

\begin{abstract}
Although the pathogenesis underlying behavioral variant frontotemporal dementia (bvFTD) has yet to be fully understood, glutamatergic abnormalities have been hypothesized to play an important role. The aim of the present study was to determine the availability of the metabotropic glutamate receptor type 5 (mGluR5) using a novel positron emission tomography (PET) radiopharmaceutical with high selectivity for mGluR5 ([ $\left[{ }^{11} \mathrm{C}\right] \mathrm{ABP} 688$ ) in a sample of bvFTD patients. In addition, we sought to determine the overlap between availability of mGluR5 and neurodegeneration, as measured using $\left[{ }^{18} \mathrm{~F}\right] \mathrm{FDG}-\mathrm{PET}$ and voxel-based morphometry (VBM). Availability of mGluR5 and glucose metabolism ( $\left.\left[{ }^{18} \mathrm{~F}\right] \mathrm{FDG}\right)$ were measured in bvFTD $(n=5)$ and cognitively normal $(\mathrm{CN})$ subjects $(n=10)$. $\left[{ }^{11} \mathrm{C}\right] \mathrm{ABP} 688$ binding potential maps $\left(\mathrm{BP}_{\mathrm{ND}}\right)$ were calculated using the cerebellum as a reference region,
\end{abstract}

A. Leuzy · E. R. Zimmer · P. Rosa-Neto $(\bowtie)$

Translational Neuroimaging Laboratory, McGill Centre for

Studies in Aging, McGill University, 6825 LaSalle Blvd,

Montreal, QC H4H 1R3, Canada

e-mail: pedro.rosa@mcgill.ca

A. Leuzy · E. R. Zimmer · S. Gauthier · P. Rosa-Neto Alzheimer's Disease Research Unit, McGill Centre for Studies in Aging, McGill University, Montreal, Canada

\section{E. R. Zimmer}

Department of Biochemistry, Federal University of Rio Grande do Sul, Porto Alegre, Brazil

\section{J. Dubois}

Department of Neurology and Neurosurgery, Montreal

Neurological Institute, McGill University, Montreal, Canada

\section{J. Pruessner}

McGill Centre for Studies in Aging, McGill University,

Montreal, Canada with $\left[{ }^{18} \mathrm{~F}\right] \mathrm{FDG}$ standardized uptake ratio maps $\left(\mathrm{SUV}_{\mathrm{R}}\right)$ normalized to the pons. Grey matter (GM) concentrations were determined using VBM. Voxel-based group differences were obtained using RMINC. BvFTD patients showed widespread decrements in $\left[{ }^{11} \mathrm{C}\right] \mathrm{ABP} 688 \mathrm{BP}_{\mathrm{ND}}$ throughout frontal, temporal and subcortical areas. These areas were likewise characterized by significant hypometabolism and GM loss, with overlap between reduced $\left[{ }^{11} \mathrm{C}\right] \mathrm{ABP} 688 \mathrm{BP}_{\mathrm{ND}}$ and hypometabolism superior to that for GM atrophy. Several regions were characterized only by decreased binding of $\left[{ }^{11} \mathrm{C}\right] \mathrm{ABP} 688$. The present findings represent the first in vivo report of decreased availability of mGluR5 in bvFTD. This study suggests that glutamate excitotoxicity may play a role in the pathogenesis of bvFTD and that $\left[{ }^{11} \mathrm{C}\right] \mathrm{ABP} 688$ may prove a suitable marker of glutamatergic neurotransmission in vivo.

\author{
J. Pruessner · C. Cooperman \\ Department of Psychiatry, Douglas Mental Health University \\ Institute, McGill University, Montreal, Canada \\ C. Cooperman \\ Department of Psychology, McGill University, Montreal, \\ Canada \\ J.-P. Soucy · A. Kostikov · E. Schirmaccher \\ McConnell Brain Imaging Centre, Montreal Neurological \\ Institute, McGill University, Montreal, Canada \\ R. Désautels \\ Division of Geriatric Psychiatry, Douglas Mental Health \\ University Institute, Montreal, Canada
}


Keywords Behavioral variant frontotemporal dementia . Frontotemporal lobar degeneration - Positron emission tomography $\cdot{ }^{11} \mathrm{C}$-ABP688 - Metabotropic glutamate receptor type $5 \cdot$ Excitotoxicity

\section{Introduction}

Behavioral variant frontotemporal dementia (bvFTD) is a progressive neurodegenerative syndrome characterized by change in personality, impaired social cognition, and executive dysfunction (Mendez et al. 2008; Swartz et al. 1997). Approaching Alzheimer's disease (AD) as the leading cause of early-onset (before 65 years of age) dementia (Ratnavalli et al. 2002; Rosso et al. 2003), bvFTD arises from a heterogeneous range of pathologies-referred to collectively as frontotemporal lobar degeneration (FTLD)_resulting in degenerative changes within frontal paralimbic, temporal and subcortical brain regions. In most cases, patients show either deposition of the microtubule associated protein tau (tau) or the TAR DNA-binding protein of $43 \mathrm{kDa}$ (TDP) (Mackenzie et al. 2010). A minority, however, show a defect in metabolism of the tumor-associated protein fused in sarcoma (FUS). The majority of FTLDs can therefore be classified into FTLD-tau, FTLD-TDP, or FTLD-FUS, with further subclassification based predominantly on inclusion morphology and lesion distribution (Mackenzie et al. 2010).

Although the pathogenic mechanisms underlying bvFTD have yet to be fully elucidated, aberrant glutamatergic neurotransmission has been hypothesized to play a role. The primary excitatory neurotransmitter in the mammalian brain, glutamate acts via ionotropic and metabotropic receptors (Schaeffer and Duplantier 2010). Whereas ionotropic receptors mediate fast excitatory neurotransmission, metabotropic glutamate receptors (mGluRs) play an important role in synaptic modulation via regulation of neuronal excitability, transmitter release, synaptic plasticity and glial function. In the case of bvFTD, FTLD has been found to accumulate preferentially within paralimbic and homotypical heteromodal brain regions, areas rich in excitatory glutamatergic pyramidal cells. Indeed, several autoradiographic and immunohistochemical studies in post-mortem bvFTD tissue have provided evidence supporting this hypothesis (Dalfo et al. 2005; Ferrer 1999; Procter et al. 1999), highlighting reduced expression of the $N$-methyl-D-aspartate (NMDA) ionotropic glutamate receptor. Importantly, activation of mGluR5 was shown to regulate glutamatergic neurotransmission via modulation of NMDA receptor functionality (Llansola and Felipo 2010; Niswender and Conn 2010; Perroy et al. 2008). Moreover, mGluR5 signaling has been shown to be critically involved in the normal cognitive functioning of various neuronal populations (Schaeffer and Duplantier 2010), including those within FTLD predilection sites (Ferraguti and Shigemoto 2006).

Despite a strong in vitro evidence base, glutamatergic abnormalities in bvFTD have yet to be systematically characterized in vivo owing to the lack of suitable molecular probes. Using $\left[{ }^{11} \mathrm{C}\right] \mathrm{ABP} 688$ - a novel positron emission tomography (PET) radiopharmaceutical with high selectivity for mGluR5 (Ametamey et al. 2006, 2007)—we sought to measure mGluR5 availability and to determine the topographic overlap with neurodegeneration within frontotemporal and subcortical brain regions, as indexed using $\left[{ }^{18} \mathrm{~F}\right]$ fluorodeoxyglucose $\left(\left[{ }^{18} \mathrm{~F}\right] \mathrm{FDG}\right)$-PET and voxelbased morphometry (VBM).

\section{Methods}

\section{Subjects}

Five patients meeting research criteria for probable bvFTD (Rascovsky et al. 2011) were recruited from the McGill Centre for Studies in Aging (MCSA) Alzheimer's Disease Research Unit. Exclusion criteria were (1) past or present use of memantine; (2) presence of other neurological diseases; (3) premorbid psychiatric disease or intellectual disability; (4) history of head injuries and loss of consciousness following head trauma; (5) current (within 1 month) use of psychoactive substances; (6) parkinsonism-as identified using the United Parkinson's Disease Rating Scale (Goetz et al. 2007)—and (7) the presence of any major structural anomaly or signs of major vascular pathology on magnetic resonance imaging (MRI) evaluation (Roman et al. 1993). All patients underwent neuropsychological assessment and behavioral testing. Global cognition was assessed using the Mini-Mental State Examination (MMSE) (Folstein et al. 1975), with language and visuospatial function measured using the Wechsler Abbreviated Scale of Intelligence, second edition (McCrimmon and Smith 2013). The Cogstate Research test battery was used to assess executive function, episodic memory, and social cognition (http://cogstate.com/tag/cog state-brief-battery/). The choice of measures included in the overall assessment battery took into consideration test availability in both English and French. Behavioral measures included the Neuropsychiatric Inventory (NPI) (Cummings et al. 1994), and the Frontal Behavioral Inventory (FBI) (Kertesz et al. 1997). In addition, given that bvFTD and the frontal variant of AD are often difficult to differentiate on clinical grounds alone (Alladi et al. 2007), all patients underwent carbon-11 Pittsburgh Compound $\mathrm{B}\left(\left[{ }^{11} \mathrm{C}\right] \mathrm{PiB}\right) \mathrm{PET}$ to rule out the presence of 
amyloid pathology. The diagnosis of bvFTD was determined during a multidisciplinary conference taking into consideration available medical, clinical, imaging, neuropsychological, and complementary laboratory information.

The bvFTD patients were matched by age and gender to a group of 10 cognitively normal $(\mathrm{CN})$ controls, recruited via advertisements in a local newspaper. $\mathrm{CN}$ subjects were identified as individuals who (1) were independently functioning community dwellers; (2) did not have a personal or first degree relative history of psychiatric disorders; (3) had no cognitive complaints; (4) had a normal neurological and psychometric examination; (5) were not taking any psychoactive medications; (6) had no history of head trauma; (7) showed no signs of vascular pathology on MRI evaluation (Roman et al. 1993) and (8) had an MMSE score $\geq 29$, an NPI score of 0 , and an FBI score of 0 .

Demographic and clinical data for all subjects are shown in Table 1, with ratings of lobar atrophy (Kipps et al. 2007) and hypometabolism (Poljansky et al. 2011) for bvFTD

Table 1 Demographic and clinical data for all subjects

\begin{tabular}{llll}
\hline & $\begin{array}{l}\text { BvFTD } \\
(n=5)\end{array}$ & $\begin{array}{l}\text { CN } \\
(n=10)\end{array}$ & $\begin{array}{l}p^{\mathrm{a}} \\
\text { value }\end{array}$ \\
\hline Age at scan, Med (IQR), years & $65(7)$ & $63(2.75)$ & 0.65 \\
Education, Med (IQR), years & $10(5)$ & $16(4)$ & 0.06 \\
Sex, M/F & $3 / 2$ & $7 / 3$ & 1.00 \\
Handedness, R/L & $5 / 0$ & $9 / 1$ & 0.52 \\
MMSE, Med (IQR), & $26(1)$ & $30(1)$ & 0.03 \\
$\quad$ max = 30 & & & \\
FBI, Med (IQR), max $=72$ & $20(0)$ & $0(0)$ & 0.001 \\
NPI Total, Med (IQR), & $32(8)$ & $0(0)$ & 0.001 \\
$\quad$ max =144 & & & \\
\end{tabular}

Due to the small group sizes, data are represented as Med $(\mathrm{IQR})=$ median (interquartile range)

$M / F$ male/female, $R / L$ right/left, MMSE Mini-Mental State Examination, FBI Frontal Behavioral Inventory, NPI Neuropsychiatric Inventory

${ }^{a}$ The $t$ test for continuous variables, Fischer's exact test for categorical variables patients shown in Table 2. All subjects and their caregivers provided written informed consent. The study protocol, approved by the Research Ethics Board of the Montreal Neurological Institute as well as by the Faculty of Medicine Research Ethics Office, McGill University, was carried out in accordance with the Declaration of Helsinki.

\section{PET acquisition}

3-(6-Methyl-pyridin-2-ylethynyl)-cyclohex-2-enone- $O-{ }^{11} \mathrm{C}$ methyl-oxime ( $\left.\left[{ }^{11} \mathrm{C}\right] \mathrm{ABP} 688\right)$ was synthesized as described previously (Elmenhorst et al. 2010), with a radiochemical purity $>99 \%$. The study was performed using a high-resolution research tomograph (HRRT) PET scanner (CTI/ Siemens, Knoxville, Tennessee), a brain-dedicated tomograph combining high spatial image resolution with high sensitivity. Prior to radiopharmaceutical administration, a 6-min transmission scan was acquired for scatter and attenuation correction using a $\left[{ }^{137} \mathrm{Cs}\right]$ rotating point source. A 60-min dynamic list-mode emission scan was started concomitantly with the venous injection of $370 \mathrm{MBq}$ (mean specific activity $>500 \mathrm{Ci} / \mu \mathrm{mol}$ ) of $\left[{ }^{11} \mathrm{C}\right] \mathrm{ABP} 688$, with emission data acquired in list-mode format, and binned into 26 time frames. For each and every time frame, sets of fully 3D sinograms were generated from the list-mode data (2,209 sinograms, span 9, with 256 radial bins and 288 azimuthal angle samples). A time-series of $263 \mathrm{D}$ images (frame duration: $6 \times 30 \mathrm{~s}, 4 \times 60 \mathrm{~s}$, $8 \times 120 \mathrm{~s}, 3 \times 240 \mathrm{~s}, 5 \times 300 \mathrm{~s})$ were then reconstructed from these sinograms, each $3 \mathrm{D}$ image being composed of $256 \times 256 \times 207$ cubic voxels (voxel side-length of $1.21875 \mathrm{~mm}$ ), using an expectation maximization image reconstruction algorithm with an ordinary Poisson model of the acquired PET data. The reconstruction included full accounting for the normalization, attenuation, and timedependent scatter of random events. To reduce the partial volume effect, resolution modeling with point-spread function was implemented in the reconstruction (Comtat et al. 2008). Subject head-motion correction was

Table 2 Ratings of hypometabolism and lobar atrophy in patients with bvFTD

\begin{tabular}{|c|c|c|c|c|c|c|c|c|c|}
\hline \multicolumn{8}{|c|}{$\left[{ }^{18} \mathrm{~F}\right]$ FDG-PET } & \multicolumn{2}{|l|}{ MRI } \\
\hline Subject & $\begin{array}{l}\text { Frontal } \\
\text { lobe }\end{array}$ & $\begin{array}{l}\text { Temporal } \\
\text { lobe }\end{array}$ & $\begin{array}{l}\text { Parietal } \\
\text { lobe }\end{array}$ & $\begin{array}{l}\text { Occipital } \\
\text { lobe }\end{array}$ & Cerebellum & $\begin{array}{l}\text { Basal } \\
\text { ganglia }\end{array}$ & Thalamus & $\begin{array}{l}\text { Frontal } \\
\text { lobe }\end{array}$ & $\begin{array}{l}\text { Anterior temporal } \\
\text { lobe }\end{array}$ \\
\hline 1 & 2 & 2 & 1 & 0 & 0 & 0 & 1 & 3 & 2 \\
\hline 2 & 2 & 2 & 1 & 0 & 0 & 0 & 0 & 1 & 1 \\
\hline 3 & 2 & 2 & 1 & 0 & 0 & 0 & 0 & 3 & 3 \\
\hline 4 & 2 & 2 & 1 & 0 & 0 & 0 & 0 & 1 & 2 \\
\hline 5 & 2 & 2 & 1 & 0 & 0 & 0 & 1 & 1 & 2 \\
\hline
\end{tabular}

Ratings for $\left[{ }^{18}\right.$ F]FDG-PET: 0 absent, 1 mild, 2 moderate, 3 strong

Ratings for MRI: 1 very mild, 2 mild, 3 moderate 
implemented using a data-driven motion estimation and correction method (Costes et al. 2009).

All patients underwent an $\left[{ }^{18} \mathrm{~F}\right] \mathrm{FDG}-\mathrm{PET}$ scan using a Siemens ECAT EXACT HR+ PET device (CTI/Siemens, Knoxville, TN, USA) as part of their clinical evaluation. In keeping with the ALARA radiation safety principle (Natarajan et al. 2013), data were not recollected on the HRRT. After fasting overnight, patients received a venous bolus injection of $185 \mathrm{MBq}$ of ${ }^{18} \mathrm{~F}$-fluorodeoxyglucose $\left(\left[{ }^{18} \mathrm{~F}\right] \mathrm{FDG}\right)$ in a quiet environment. A dynamic scan was performed in 3-dimensional mode for 10 min under standard resting-state conditions with eyes open, recording 63 transaxial slices simultaneously with an axial resolution of $5 \mathrm{~mm}$ full width at half maximum (FWHM) and an inplane resolution of $4.6 \mathrm{~mm}$. Each collected slice had a thickness of $2.45 \mathrm{~mm}$ and a matrix size of $128 \times 128$ voxels. After correction for attenuation, scatter, decay and scanner-specific dead time, the PET data were reconstructed by filtered back-projection using a Hann filter (4.9 mm FWHM).

CN subjects had their acquisition conducted on the HRRT, with acquisition parameters identical to those for $\left[{ }^{11} \mathrm{C}\right] \mathrm{ABP} 688$, as described above. Images were reconstructed taking into consideration data acquired between 45 and $60 \mathrm{~min}$ only, with reconstruction matching that used for the HR+ data. In order to compare data from the HRRT and HR+ PET scanners, the resolution of the HRRT was matched to the partial volume effect of the HR+. To do so, an anisotropic Gaussian kernel of $5.7 \times 5.7 \times 6.7 \mathrm{~mm}$ FWHM was used, which was found to be the best match of scanner resolutions through an internal phantom study (unpublished data). In the case of $\left[{ }^{18} \mathrm{~F}\right] \mathrm{FDG}$, two $\mathrm{CN}$ subjects were excluded owing to movement with one patient unable to return for the scan, reducing the sample size for $\left[{ }^{18} \mathrm{~F}\right] \mathrm{FDG}$ to $4 \mathrm{bvFTD}$ and $8 \mathrm{CN}$.

\section{Magnetic resonance imaging}

For anatomical co-registration and identification of the volumes of interest (VOI), all subjects underwent a highresolution T-1 weighted MRI using a Siemens TRIO 3T scanner (Siemens Medical Solutions, Erlangen, Germany). Images were acquired in 3-D (voxel size $=1 \mathrm{~mm}^{3}$; $\mathrm{FOV}=256 \times 256 \mathrm{~mm} ; \mathrm{TR}=22 \mathrm{~ms} ; \mathrm{TE}=9.2 \mathrm{~ms}$; flip angle $=30^{\circ}$ ), with the scan performed on either on the same day or less than 2 weeks apart from the PET acquisitions, depending on the availability of the research slots.

\section{Imaging analysis}

$\left[{ }^{11} \mathrm{C}\right] \mathrm{ABP} 688$ binding potential, non-displaceable $\left(\mathrm{BP}_{\mathrm{ND}}\right)$ values were obtained using the simplified reference tissue method (SRTM) (Gunn et al. 1997), using the cerebellum as a reference region (Elmenhorst et al. 2009; Minuzzi et al. 2009). [ $\left.{ }^{18} \mathrm{~F}\right]$ FDG-PET frames were summed and standardized uptake value ratio $\left(\mathrm{SUV}_{\mathrm{R}}\right)$ maps calculated by normalizing the summed image to mean pontine activity for each subject. In order to correct for partial volume error (PVE), a modified version (Greve et al. 2014; Rousset et al. 2007) of the Muller-Gartner method (Muller-Gartner et al. 1992; Rousset et al. 1998) was implemented using the PVElab software package (https://nru.dk/downloads/soft ware/pveout/pveout.html) (Quarantelli et al. 2004).

Following correction for field inhomogeneities (Sled and Evans 1998), native MRI volumes were nonlinearly resampled into standardized stereotaxic space, using the high-resolution ICBM template as reference (Fonov et al. 2009). Subsequently, normalized images were classified into grey matter (GM), white matter (WM) and cerebrospinal fluid (CSF) using an automatic algorithm (INSECT) (Zijdenbos and Evans 1998). Voxel-based morphometry (VBM) (Ashburner and Friston 2000) was carried out on the structural segmented GM images nonlinearly resampled to the standard stereotaxic space after blurring with an isotropic Gaussian kernel of $10 \mathrm{~mm}$ FWHM. Finally, classified images were resampled to an anatomical template and automatically labeled using a probabilistic atlasbased approach (ANIMAL) (Collins et al. 1999; Collins and Evans 1997). VOIs yielded by this procedure were subsequently applied to PET $\mathrm{BP}_{\mathrm{ND}}$ (cerebellum) and $\mathrm{SUV}_{\mathrm{R}}$ maps (pons).

Voxel-wise analysis maps of $\left[{ }^{11} \mathrm{C}\right] \mathrm{ABP} 688 \mathrm{BP}_{\mathrm{ND}}$, $\left[{ }^{18} \mathrm{~F}\right] \mathrm{FDG} \mathrm{SUV}_{\mathrm{R}}$, and VBM values were estimated using a basis functions approach (Gunn et al. 1997), with PET images convolved using an isotropic Gaussian kernel of $6 \mathrm{~mm}$ FWHM. Parametric maps created in native space were then normalized into MNI space in order to allow for group comparisons. The resulting t-maps, calculated using RMINC (Lerch 2006), show the areas with a significant difference in $\mathrm{BP}_{\mathrm{ND}}, \mathrm{SUV}_{\mathrm{R}}$, and relative concentration of GM between groups. Those areas were subsequently adjusted for a statistical cluster-wise threshold of $p<0.05$, and corrected for multiple comparisons using random field theory (Worsley et al. 1998). $\left[{ }^{11} \mathrm{C}\right] \mathrm{ABP} 688 \mathrm{BP}_{\mathrm{ND}}$ local maxima coordinates were used to extract $\left[{ }^{18} \mathrm{~F}\right] \mathrm{FDG} \mathrm{SUV}_{\mathrm{R}}$, and VBM values, in order to compare the magnitude of decline.

Brain regions where all patients differed significantly from controls on the basis of $Z$ scores $\geq 2$-calculated using the formula [(individual patient value) - (control mean)/(control standard deviation)]-were calculated for $\left[{ }^{11} \mathrm{C}\right] \mathrm{ABP} 688 \mathrm{BP}_{\mathrm{ND}},\left[{ }^{18} \mathrm{~F}\right] \mathrm{FDG} \mathrm{SUV}_{\mathrm{R}}$, and VBM t-maps. These areas were then used to extract raw $\left[{ }^{11} \mathrm{C}\right] \mathrm{ABP} 688$ $\mathrm{BP}_{\mathrm{ND}},\left[{ }^{18} \mathrm{~F}\right] \mathrm{FDG} \mathrm{SUV}_{\mathrm{R}}$, and VBM values, which, after reconversion to $Z$ scores, were plotted using GraphPad Prism 5 software. Overlap maps- $\left[{ }^{11} \mathrm{C}\right] \mathrm{ABP} 688 \mathrm{BP}_{\mathrm{ND}}$ and 


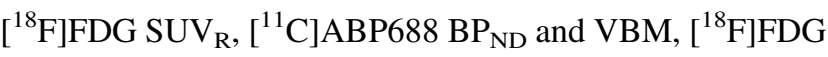
$\mathrm{SUV}_{R}$ and VBM-as well as areas showing only reduced $\left[{ }^{11} \mathrm{C}\right] \mathrm{ABP} 688 \mathrm{BP}_{\mathrm{ND}},\left[{ }^{18} \mathrm{~F}\right] \mathrm{FDG}$ SUVR, and VBM-were created using MINC tools (http://www.bic.mni.mcgill.ca/ ServicesSoftware/MINC). For overlap maps, binary masks were generated by applying the cluster-corrected t-map thresholds to each individual t-map- $\left[{ }^{11} \mathrm{C}\right] \mathrm{ABP} 688 \mathrm{BP}$ ND, $\left[{ }^{18} \mathrm{~F}\right] \mathrm{FDG} \mathrm{SUV}_{\mathrm{R}}$, and VBM-setting voxels less than the given threshold to 0 and voxels greater than the threshold to 1 . Binary masks were then summed, with voxels having a value of 2 indicating overlap. In order to show areas exhibiting only reductions (e.g., in availability of mGluR5) binary masks were subtracted (e.g., $\left[{ }^{11} \mathrm{C}\right] \mathrm{ABP} 688 \mathrm{BP}_{\mathrm{ND}}-$ $\left[{ }^{18}\right.$ F]FDG $\left.S_{U V}-V B M\right)$, with the range of values in the resulting volume restricted to lie between 0 and 1 , removing negative values generated as a result of the subtraction. Finally, volumes were visualized and colorcoded using the software DISPLAY (http://www.bic.mni. mcgill.ca/software/Display/Display.html).

\section{Results}

Groups differed significantly in terms of MMSE, FBI and NPI (see Table 1). No differences were observed for age at scan, education, sex, or handedness. Since only two patients were capable of completing the entire neuropsychological assessment battery, quantitative assessment proved uninformative. Qualitative assessment based on the expert judgement of neuropsychologists (JP and CC) indicated clear deficits in executive and social cognitive measures in all bvFTD patients. Two patients displayed abnormal performance on measures of abstract and concrete language, with three showing deficits in visuospatial processing. While all patients showed moderate hypometabolism within frontotemporal regions, atrophy ranged from very mild to moderate (see Table 2).

$Z$ score maps for regions with significantly reduced $\left[{ }^{11} \mathrm{C}\right] \mathrm{ABP} 688 \mathrm{BP}_{\mathrm{ND}}$, hypometabolism and atrophy common to all patients-along with plots showing $Z$ scores relative to controls are shown in Fig. 1. Location and coordinates of local maxima for the contrast $\left[{ }^{11} \mathrm{C}\right] \mathrm{ABP} 688$ $\mathrm{BP}_{\mathrm{ND}} \mathrm{CN}>$ bvFTD] are reported in Table 3, along with values for $\left[{ }^{18} \mathrm{~F}\right] \mathrm{FDG} \mathrm{SUV}_{\mathrm{R}}$ and VBM using these local maxima. Despite neurodegeneration being more widespread than declines in mGluR5 availability, reductions in metabolism and GM were found to be inferior to those for $\left[{ }^{11} \mathrm{C}\right] \mathrm{ABP} 688 \mathrm{BP}_{\mathrm{ND}}$ across a wide range of FTLD predilection sites (see Table 3). Relative to controls, bvFTD patients showed reductions of 65,30 , and $15 \%$-for $\left[{ }^{11} \mathrm{C}\right] \mathrm{ABP} 688 \mathrm{BP}_{\mathrm{ND}},\left[{ }^{18} \mathrm{~F}\right] \mathrm{FDG} \mathrm{SUV}_{\mathrm{R}}$, and VBM, respectively - on the basis of values extracted from common $Z$ score maps.

Voxel-wise analysis of group differences in $\left[{ }^{11} \mathrm{C}\right] \mathrm{ABP} 688 \mathrm{BP}_{\mathrm{ND}}$ revealed declines in mGluR5 availability $\left(85,152 \mathrm{~mm}^{3}\right)$ in orbital, ventromedial, and
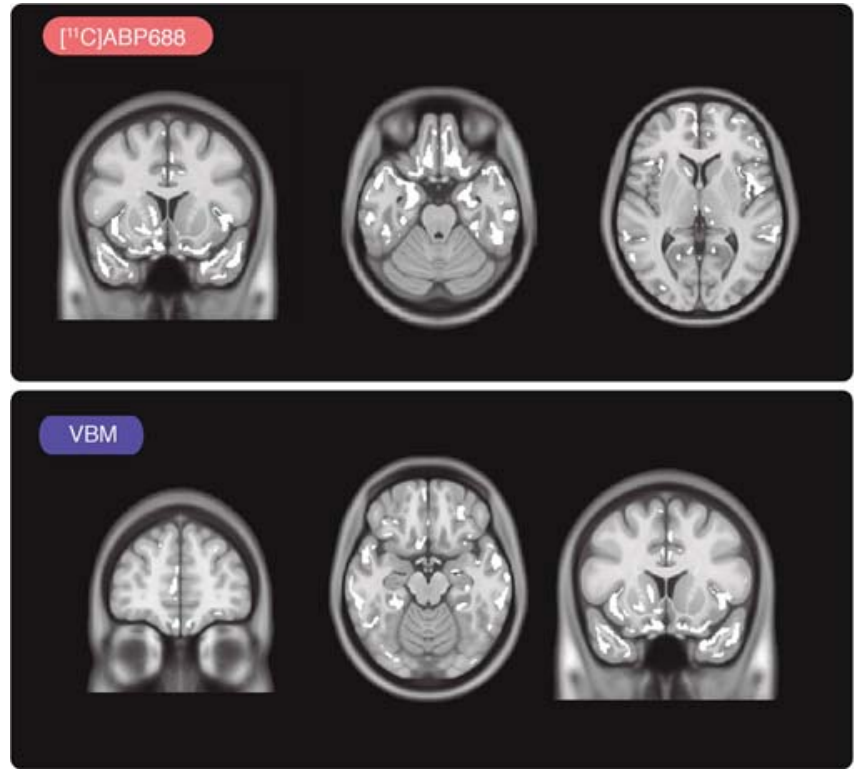

Fig. $1 Z$ score maps for all bvFTD patients were created for $\left[{ }^{11} \mathrm{C}\right] \mathrm{ABP} 688 \mathrm{BP}_{\mathrm{ND}},\left[{ }^{18} \mathrm{~F}\right] \mathrm{FDG} \mathrm{SUV}_{\mathrm{R}}$, and VBM. These maps were then combined to show areas with significantly reduced $\left[{ }^{11} \mathrm{C}\right] \mathrm{ABP} 688$ $\mathrm{BP}_{\mathrm{ND}},\left[{ }^{18} \mathrm{~F}\right] \mathrm{FDG} \mathrm{SUV}_{\mathrm{R}}$, and GM common to all bvFTD patients (top left, top right, bottom left, respectively). These common $Z$ maps were
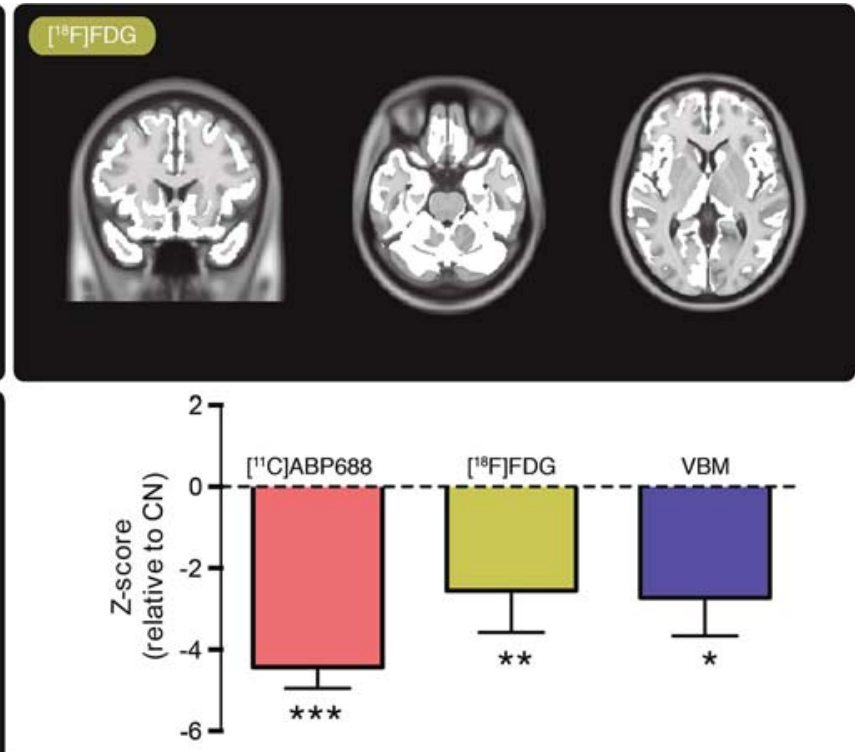

then used to extract raw $\left[{ }^{11} \mathrm{C}\right] \mathrm{ABP} 688 \mathrm{BP}_{\mathrm{ND}},\left[{ }^{18} \mathrm{~F}\right] \mathrm{FDG} \mathrm{SUV} \mathrm{S}_{\mathrm{R}}$, and $\mathrm{VBM}$ values. After conversion to $Z$ scores, values were plotted, relative to $\mathrm{CN}$ subjects (bottom right). ${ }^{* * *} p<0.001$, $* * p<0.01$, $* p<0.05$ 
Table 3 Location and Talairach coordinates of local maxima for areas of reduced $\left[{ }^{11} \mathrm{C}\right] \mathrm{ABP} 688 \mathrm{BP}_{\mathrm{ND}}$ in patients with bvFTD, along with $t$ values for $\left[{ }^{18} \mathrm{~F}\right] \mathrm{FDG} \mathrm{SUV}_{\mathrm{R}}$ and $\mathrm{VBM}$ findings, using $\left[{ }^{11} \mathrm{C}\right] \mathrm{ABP} 688 \mathrm{BP}_{\mathrm{ND}}$ maxima coordinates

\begin{tabular}{|c|c|c|c|c|c|c|c|c|c|}
\hline Brain region & $x$ & $y$ & $z$ & $t_{[11 \mathrm{C}] \mathrm{ABP} 688}$ & $p$ & $t_{[18 \mathrm{~F}] \mathrm{FDG}}$ & $p$ & $t_{\mathrm{VBM}}$ & $p$ \\
\hline Gyrus rectus L & -9.0 & 28.2 & -24.7 & -7.12 & $>0.0001$ & -4.19 & $>0.0001$ & -2.28 & 0.0401 \\
\hline Gyrus rectus $\mathrm{R}$ & 13.8 & 26.2 & -24.7 & -6.52 & $>0.0001$ & -3.22 & 0.0092 & -2.38 & 0.0333 \\
\hline Medial orbitofrontal cortex L & -16.0 & 23.1 & -15.2 & -8.49 & $>0.0001$ & -2.40 & 0.0373 & -0.527 & 0.6071 \\
\hline Medial orbitofrontal cortex R & 15.0 & -15.2 & -9.66 & -9.73 & $>0.0001$ & -1.98 & 0.0076 & -0.002 & 0.9998 \\
\hline Lateral orbitofrontal cortex L & -32.1 & 36.0 & -15.2 & -4.63 & 0.0005 & -4.14 & 0.0020 & -4.03 & 0.0014 \\
\hline Lateral orbitofrontal cortex R & 28.1 & 47.2 & -15.2 & -5.21 & 0.0002 & 2.59 & 0.0269 & -4.45 & 0.0007 \\
\hline Ventromedial prefrontal cortex L & -2.9 & 51.3 & 4.0 & -7.42 & $>0.0001$ & -5.55 & 0.0002 & $-5.6 \mathrm{t} 9$ & $>0.0001$ \\
\hline Ventromedial prefrontal cortex $\mathrm{R}$ & 13.3 & 53.2 & 2.5 & -4.42 & 0.0007 & -2.01 & 0.0722 & -3.32 & 0.0055 \\
\hline Dorsomedial prefrontal cortex L & -3.6 & 56.9 & 28.0 & -6.14 & $>0.0001$ & -4.56 & 0.0010 & -1.43 & 0.1763 \\
\hline Dorsomedial prefrontal cortex $\mathrm{R}$ & 3.3 & 42.0 & 34.2 & -4.11 & 0.0012 & -4.88 & 0.0006 & -4.29 & 0.0009 \\
\hline Anterior cingulate $\mathrm{L}$ & -2.4 & 37.0 & 14.7 & -4.93 & 0.0003 & -4.03 & 0.0024 & -5.00 & 0.0002 \\
\hline Anterior cingulate $\mathrm{R}$ & 5.0 & 40.2 & 14.7 & -4.40 & 0.0007 & -3.97 & 0.0026 & -5.66 & $>0.0001$ \\
\hline Frontal pole L & -10.1 & 71.1 & 3.0 & -4.85 & 0.0003 & -2.79 & 0.0191 & -1.53 & 0.1500 \\
\hline Frontal pole $\mathrm{R}$ & 14.2 & 72.0 & 3.0 & -4.81 & 0.0003 & -2.59 & 0.0269 & -1.42 & 0.1791 \\
\hline Dorsolateral prefrontal cortex $\mathrm{L}$ & - & - & - & - & - & - & - & - & - \\
\hline Dorsolateral prefrontal cortex $\mathrm{R}$ & 52.1 & 25.1 & 21.8 & -8.3 & $>0.0001$ & -5.01 & 0.0005 & -1.51 & 0.1550 \\
\hline Ventrolateral prefrontal cortex L & - & - & - & - & - & - & - & - & - \\
\hline Ventrolateral prefrontal cortex $\mathrm{R}$ & 52.1 & 38.9 & -4.9 & -5.87 & $>0.0001$ & -5.28 & 0.0004 & -0.96 & 0.3546 \\
\hline Paracentral lobule L & -4.6 & -26.9 & 64.5 & -5.09 & 0.0002 & -1.98 & 0.0759 & -2.34 & 0.0359 \\
\hline Paracentral lobule $\mathrm{R}$ & 7.0 & -35.9 & -55.1 & -4.11 & 0.0002 & -1.98 & 0.0759 & -1.52 & 0.0152 \\
\hline Thalamus L & -17.8 & -31.3 & 1.8 & -6.50 & $>0.0001$ & -3.11 & 0.0111 & -8.74 & $>0.0001$ \\
\hline Thalamus R & 9.0 & -15.9 & 1.8 & -4.74 & 0.0004 & -1.93 & 0.0824 & -9.66 & $>0.0001$ \\
\hline Hypothalamus L & -5.1 & -5.9 & -11.1 & -4.18 & 0.0011 & -2.32 & 0.0428 & -8.49 & $>0.0001$ \\
\hline Hypothalamus $\mathrm{R}$ & 4.1 & -5.9 & -11.2 & -4.26 & 0.0009 & -2.67 & 0.0235 & -8.34 & $>0.0001$ \\
\hline Caudate L & -11.2 & 14.1 & 1.8 & -5.43 & 0.0001 & -4.65 & 0.0009 & -5.89 & $>0.0001$ \\
\hline Caudate R & 9.0 & 9.1 & 7.3 & -3.96 & 0.0016 & -4.16 & 0.0019 & -1.05 & 0.3128 \\
\hline Putamen L & -26.2 & 17.1 & 1.8 & -4.74 & 0.0004 & -3.64 & 0.0445 & -3.81 & 0.0022 \\
\hline Putamen R & - & - & - & - & - & - & - & - & - \\
\hline Insula L & -41.1 & 13.0 & -9.8 & -4.55 & 0.0005 & -3.59 & 0.0049 & -4.11 & 0.0012 \\
\hline Insula $\mathrm{R}$ & 41.7 & 14.1 & -2.0 & -5.76 & $>0.0001$ & -4.32 & 0.0015 & -5.78 & $>0.0001$ \\
\hline Temporal pole $\mathrm{L}$ & -38.1 & 22.2 & -35.9 & -5.59 & $>0.0001$ & -4.13 & 0.0020 & -2.02 & 0.0645 \\
\hline Temporal pole $\mathrm{R}$ & 31.1 & 22.2 & -39.0 & -6.79 & $>0.0001$ & -2.75 & 0.0205 & -1.56 & 0.1428 \\
\hline Superior temporal gyrus L & -58.2 & -10.9 & 2.0 & -3.96 & 0.0016 & -4.07 & 0.0023 & -1.74 & 0.1055 \\
\hline Superior temporal gyrus $\mathrm{R}$ & 49.4 & -2.4 & -4.0 & -6.61 & $>0.0001$ & -3.21 & 0.0093 & -4.78 & 0.0004 \\
\hline Middle temporal gyrus L & -58.2 & -16.0 & -11.0 & -4.60 & 0.0005 & -4.00 & 0.0024 & -1.29 & 0.2195 \\
\hline Middle temporal gyrus $\mathrm{R}$ & 52.7 & -12.1 & -24.0 & -6.99 & $>0.0001$ & -4.53 & 0.0011 & -1.53 & 0.1500 \\
\hline Inferior temporal gyrus L & -58.2 & -24.5 & -25.4 & -7.19 & $>0.0001$ & -3.95 & 0.0027 & -0.16 & 0.8753 \\
\hline Inferior temporal gyrus $\mathrm{R}$ & 52.7 & -45.1 & -22.9 & -5.16 & 0.0002 & -3.65 & 0.0045 & -0.09 & 0.9297 \\
\hline Hippocampal formation $\mathrm{L}$ & -35.1 & -11.8 & -19.2 & -4.94 & 0.0003 & -1.00 & 0.3409 & -1.62 & 0.1292 \\
\hline Hippocampal formation $\mathrm{R}$ & 34.5 & -14.6 & -18.5 & -1.99 & 0.0680 & -2.77 & 0.0198 & -3.26 & 0.0062 \\
\hline Cuneus L & -11.2 & -92.9 & 15.9 & -5.22 & 0.0002 & -3.35 & 0.0074 & -4.81 & 0.0003 \\
\hline Cuneus R & 13.8 & -90.8 & 15.9 & -5.27 & 0.0002 & -2.05 & 0.0611 & -4.69 & 0.0004 \\
\hline Lingual gyrus L & -12.7 & -73.7 & -1.7 & -6.87 & $>0.0001$ & -1.27 & 0.2328 & -5.52 & $>0.0001$ \\
\hline Lingual gyrus $\mathrm{R}$ & 22.8 & -79.1 & -3.9 & -7.17 & $>0.0001$ & -0.41 & 0.6905 & -0.26 & 0.7983 \\
\hline
\end{tabular}

standardized uptake ratio $\left(\mathrm{SUV}_{\mathrm{R}}\right)$; voxel-based morphometry $(\mathrm{VBM})$; non-displaceable binding potentials $\left(\mathrm{BP}_{\mathrm{ND}}\right)$. Talairach coordinates $(x, y$, $z$ ) of $\left[{ }^{11} \mathrm{C}\right] \mathrm{ABP} 688 \mathrm{BP}_{\mathrm{ND}}$ local maxima $(t$ values, corrected for multiple comparisons, $p<0.05)$ were applied to $\left[{ }^{18} \mathrm{~F}\right] \mathrm{FDG} \mathrm{SUV} \mathrm{R}_{\mathrm{R}}$ and $\mathrm{VBM}$ $\mathrm{t}$-maps in order to extra $t$ values. $\mathrm{p}$ values were determined using $t$ values and degrees of freedom $\left(\left[{ }^{11} \mathrm{C}\right] \mathrm{ABP} 688 \mathrm{BP}_{\mathrm{ND}}=14,\left[{ }^{18} \mathrm{~F}\right] \mathrm{FDG}\right.$ $\left.\mathrm{SUV}_{\mathrm{R}}=11, \mathrm{VBM}=14\right) . R$ right hemisphere, $L$ Left hemisphere, - indicates no findings in that region 


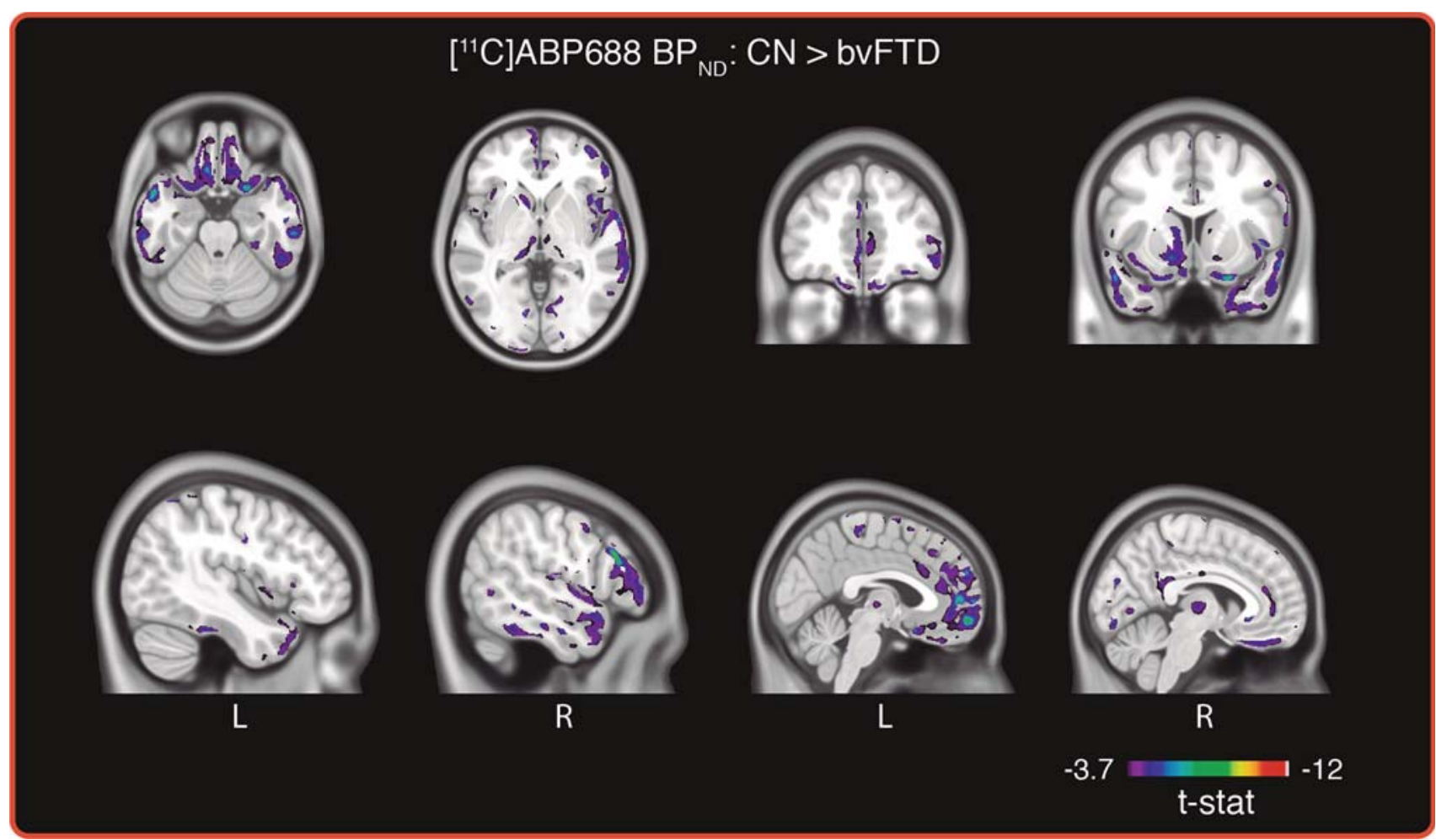

Fig. 2 Voxel-wise t-maps showing areas of decreased $\left[{ }^{11} \mathrm{C}\right] \mathrm{ABP} 688$ $\mathrm{BP}_{\mathrm{ND}}$ in patients with bvFTD compared with $\mathrm{CN}$ subjects $\left(85,152 \mathrm{~mm}^{3}\right.$; corrected for multiple comparisons, $\left.p<0.05\right)$. Leftward asymmetry was noted in the anterior cingulate, superior frontal gyrus, paracentral lobule, caudate, putamen, and thalamus. Rightward

dorsomedial prefrontal areas (corrected for multiple comparisons, $\mathrm{p}<0.05$; see Fig. 2). Declines were likewise noted in the gyrus rectus, anterior cingulate $(\mathrm{L}>\mathrm{R})$, right posterior cingulate, superior frontal gyrus $(\mathrm{L}>\mathrm{R})$, paracentral lobule $(\mathrm{L}>\mathrm{R})$, caudate $(\mathrm{L}>\mathrm{R})$, left putamen, insula $(\mathrm{R}>\mathrm{L})$, thalamus $(\mathrm{L}>\mathrm{R})$, right lingual gyrus, and right cuneus. Additional declines were found in the right dorsolateral, right ventrolateral, and anterior prefrontal cortex, the right superior and middle temporal gyri, as well as in the temporal poles. No significant increases in $\left[{ }^{11} \mathrm{C}\right] \mathrm{ABP} 688$ binding were observed in bvFTD patients.

Significant hypometabolism was noted among bvFTD patients $\left(116,742 \mathrm{~mm}^{3}\right)$ in extensive prefrontal areas, including the orbitofrontal $(\mathrm{R}>\mathrm{L})$, ventromedial and dorsomedial prefrontal $(\mathrm{L}>\mathrm{R})$, as well as the cingulate gyrus $(\mathrm{L}>\mathrm{R})$ (corrected for multiple comparisons, $p<0.05$ ) (see Fig. 3). Metabolism was significantly reduced in the superior, middle, and inferior frontal gyri as well as in the precuneus and paracentral lobule $(\mathrm{L}>\mathrm{R})$. Hypometabolism was also found in the bilateral insula $(\mathrm{R}>\mathrm{L})$, uncus/amygdala, and parahippocampus $(\mathrm{L}>\mathrm{R})$, as well as in subcortical structures, including the head of the caudatum and the left thalamus. There was also asymmetry was found in the posterior cingulate, lingual gyrus, cuneus, dorsolateral/ventrolateral prefrontal cortex, superior/middle temporal gyri and the temporal poles. No significant increases in $\left[{ }^{11} \mathrm{C}\right] \mathrm{ABP} 688$ binding were observed in bvFTD patients

hypometabolism in the superior, middle, and inferior temporal gyri, temporal poles, and cerebellar tonsils.

Among bvFTD patients, grey matter loss $\left(88,845 \mathrm{~mm}^{3}\right)$ was predominantly focused in the striatum-including the putamen $(\mathrm{L}>\mathrm{R})$ and head of the caudate nucleus bilaterally (corrected for multiple comparisons, $p<0.05$; see Fig. 4). There was significant involvement of the thalamus and insula bilaterally, as well as the amygdala, and parahippocampus. Atrophy was also observed in the anterior cingulate $(L>R)$, precuneus $(R>L)$ gyrus rectus, orbitofrontal gyrus, as well as the right superior/middle temporal gyri, though to a lesser degree (see Table 3).

Overlap between $\left[{ }^{11} \mathrm{C}\right] \mathrm{ABP} 688 \mathrm{BP}_{\mathrm{ND}}$ and $\left[{ }^{18} \mathrm{~F}\right] \mathrm{FDG}$ $\mathrm{SUV}_{\mathrm{R}} \mathrm{t}$-maps was observed in the gyrus rectus $(\mathrm{L}>\mathrm{R})$, anterior cingulate/ventromedial prefrontal cortex $(\mathrm{L}>\mathrm{R})$, dorsomedial prefrontal cortex $(\mathrm{L}>\mathrm{R})$, thalamus $(\mathrm{L}>\mathrm{R})$ insula $(\mathrm{R}>\mathrm{L})$ and temporal poles $\left(22379 \mathrm{~mm}^{3}\right.$; see Fig. 5). $\left[{ }^{11} \mathrm{C}\right] \mathrm{ABP} 688 \mathrm{BP}_{\mathrm{ND}}$ and VBM findings overlapped in the anterior cingulate/ventromedial prefrontal cortex $(\mathrm{L}>\mathrm{R})$, orbitofrontal cortex $(\mathrm{R}>\mathrm{L})$, thalamus $(\mathrm{L}>\mathrm{R})$, head of the caudate nucleus $(\mathrm{L}>\mathrm{R})$ and the insula $(\mathrm{R}>\mathrm{L})$ (13 $463 \mathrm{~mm}^{3}$; see Fig. 6). Overlap between hypometabolic regions and atrophy was noted in medial and lateral 


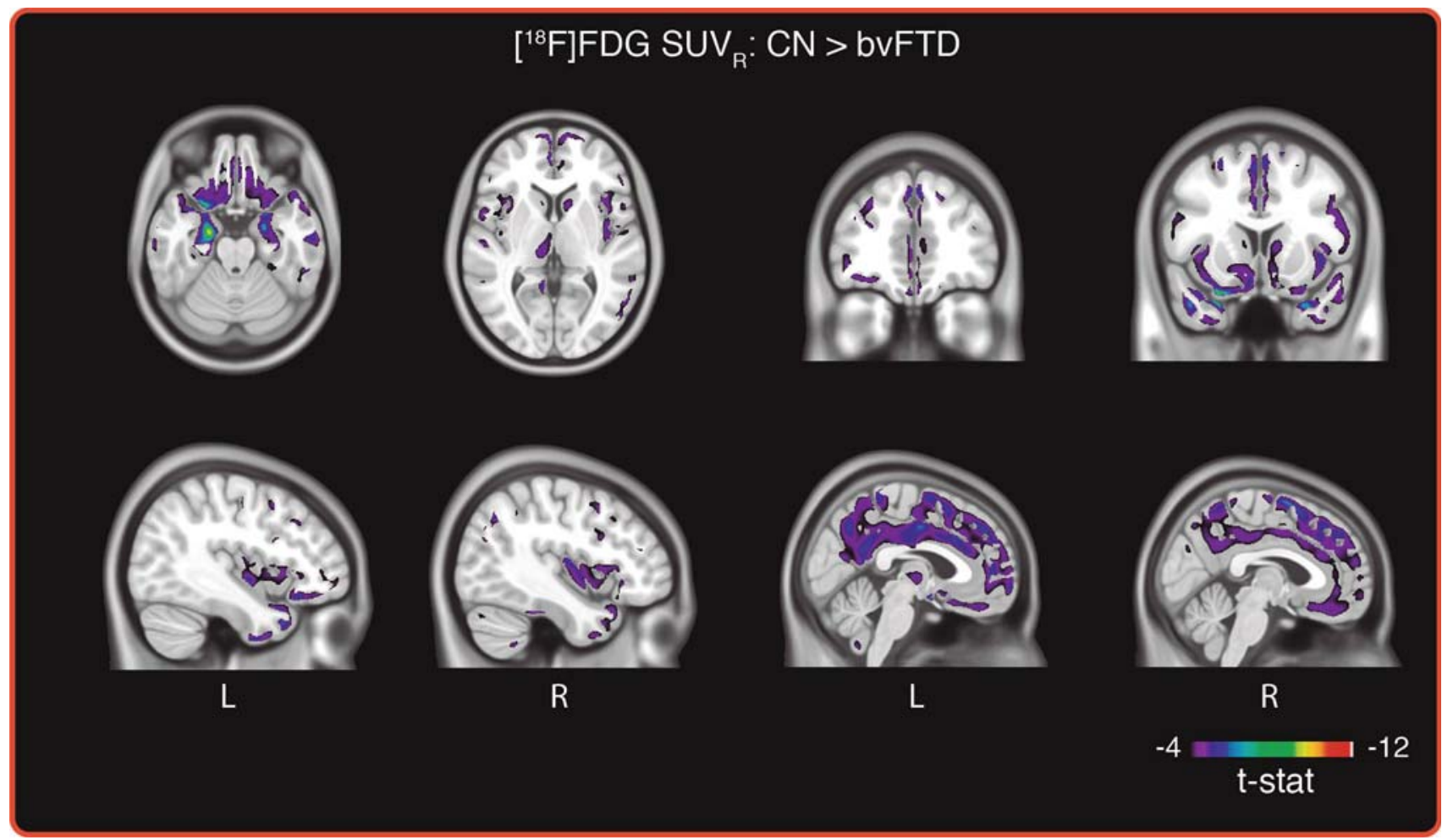

Fig. 3 Voxel-wise t-maps showing areas of decreased $\left[{ }^{18} \mathrm{~F}\right] \mathrm{FDG}$ $\mathrm{SUV}_{\mathrm{R}}$ in patients with bvFTD compared with CN subjects $\left(116,742 \mathrm{~mm}^{3}\right.$; corrected for multiple comparisons, $\left.p<0.05\right)$. The dorso/ventromedial prefrontal cortex, cingulate gyrus, frontal gyri,

orbitofrontal areas, anterior cingulate/ventromedial prefrontal cortex $(\mathrm{L}>\mathrm{R})$, dorsomedial prefrontal cortex $(\mathrm{R}>\mathrm{L})$, insula $(\mathrm{R}>\mathrm{L})$, thalamus $(\mathrm{L}>\mathrm{R})$, left amygdala, right hippocampal formation, and the head of the caudate nucleus ( $>$ L) (14 $179 \mathrm{~mm}^{3}$; see Fig. 7). Though hypometabolism and atrophy were found in frontal, temporal, and subcortical brain regions, these declines were found to be inferior relative to those for $\left[{ }^{11} \mathrm{C}\right] \mathrm{ABP} 688 \mathrm{BP}_{\mathrm{ND}}$ in a wide range of areas, including the gyrus rectus, medial and lateral orbitofrontal cortex, ventromedial prefrontal cortex, left dorsomedial prefrontal cortex, paracentral lobule, frontal pole, left putamen, left insula, lingual gyrus, cuneus, temporal poles, right superior temporal gyrus, inferior and middle temporal gyri, and the right dorso- and ventrolateral prefrontal cortex.

Subtraction of binarized t-maps $\left(\left[{ }^{11} \mathrm{C}\right] \mathrm{ABP} 688\right.$ $\left.\mathrm{BP}_{\mathrm{ND}}-\left[{ }^{18} \mathrm{~F}\right] \mathrm{FDG} \quad \mathrm{SUV}_{\mathrm{R}}-\mathrm{VBM}\right)$ showed that decreased binding of $\left[{ }^{11} \mathrm{C}\right] \mathrm{ABP} 688$ was unique to the gyrus rectus $(\mathrm{R}>\mathrm{L})$, orbitofrontal cortex $(\mathrm{R}>\mathrm{L})$, lateral portion of the right head of the caudate nucleus, left putamen, left superior temporal lobe, inferior temporal lobes, temporal poles $(\mathrm{R}>\mathrm{L})$, right posterior cingulate, right ventral/dorsolateral prefrontal cortex, left paracentral lobule, right occipital cortex, and right lingual gyrus (55 paracentral lobule, precuneus, parahippocampus, thalamus, caudate and temporal lobes were characterized by leftward asymmetry. Hypometabolism was also noted with rightward asymmetry in the insula and orbitofrontal gyrus and in the cerebellar tonsils bilaterally

$742 \mathrm{~mm}^{3}$; see Fig. 8). A similar subtraction yielded a volume of $86616 \mathrm{~mm}^{3}$ for regions displaying only hypometabolism $\quad\left(\left[{ }^{18} \mathrm{~F}\right] \mathrm{FDG} \quad \mathrm{SUV}_{\mathrm{R}}-\left[{ }^{11} \mathrm{C}\right] \mathrm{ABP} 688\right.$ $\mathrm{BP}_{\mathrm{ND}}-\mathrm{VBM}$ )-including the uncus/amygdalae $(\mathrm{L}>\mathrm{R})$, the parahippocampus $(\mathrm{L}>\mathrm{R})$, bilateral cuneus, posterior cingulate/precuneus $(\mathrm{L}>\mathrm{R})$, bilateral insula, medial prefrontal cortex, left posterior paracentral lobule, left frontal operculum, anterior temporal poles, orbitofrontal gyrus/gyrus rectus $(\mathrm{R}>\mathrm{L})$, and bilateral cerebellar cortex (see Fig. 9). In addition, the orbitofrontal gyrus, the right middle temporal gyrus, right temporal operculum, left anterior insula, posterior insula bilaterally $(\mathrm{R}>\mathrm{L})$, ventral amygdala $(L>R)$, left posterior inferior temporal gyrus, anterior cingulate gyrus $(\mathrm{L}>\mathrm{R})$, the putamen $(\mathrm{L}>\mathrm{R})$ and head of the caudate nucleus bilaterally, the thalamus as well as the posterior portion of the hippocampal formation, bilaterally, were found to be characterized only by GM reductions (VBM $-\left[{ }^{18} \mathrm{~F}\right] \mathrm{FDG}$ $\mathrm{SUV}_{\mathrm{R}}-\left[{ }^{11} \mathrm{C}\right] \mathrm{ABP} 688 \mathrm{BP}_{\mathrm{ND}} ; 67635 \mathrm{~mm}^{3}$; see Fig. 10). Though changes in $\left[{ }^{11} \mathrm{C}\right] \mathrm{ABP} 688 \mathrm{BP}_{\mathrm{ND}},\left[{ }^{18} \mathrm{~F}\right] \mathrm{FDG}$ SUVR, and VBM were found to co-exist within the orbitofrontal cortex and temporal lobe, relative to $\left[{ }^{18} \mathrm{~F}\right] \mathrm{FDG}$ and VBM, findings for $\left[{ }^{11} \mathrm{C}\right] \mathrm{ABP} 688$ were more ventral and lateral, respectively. 


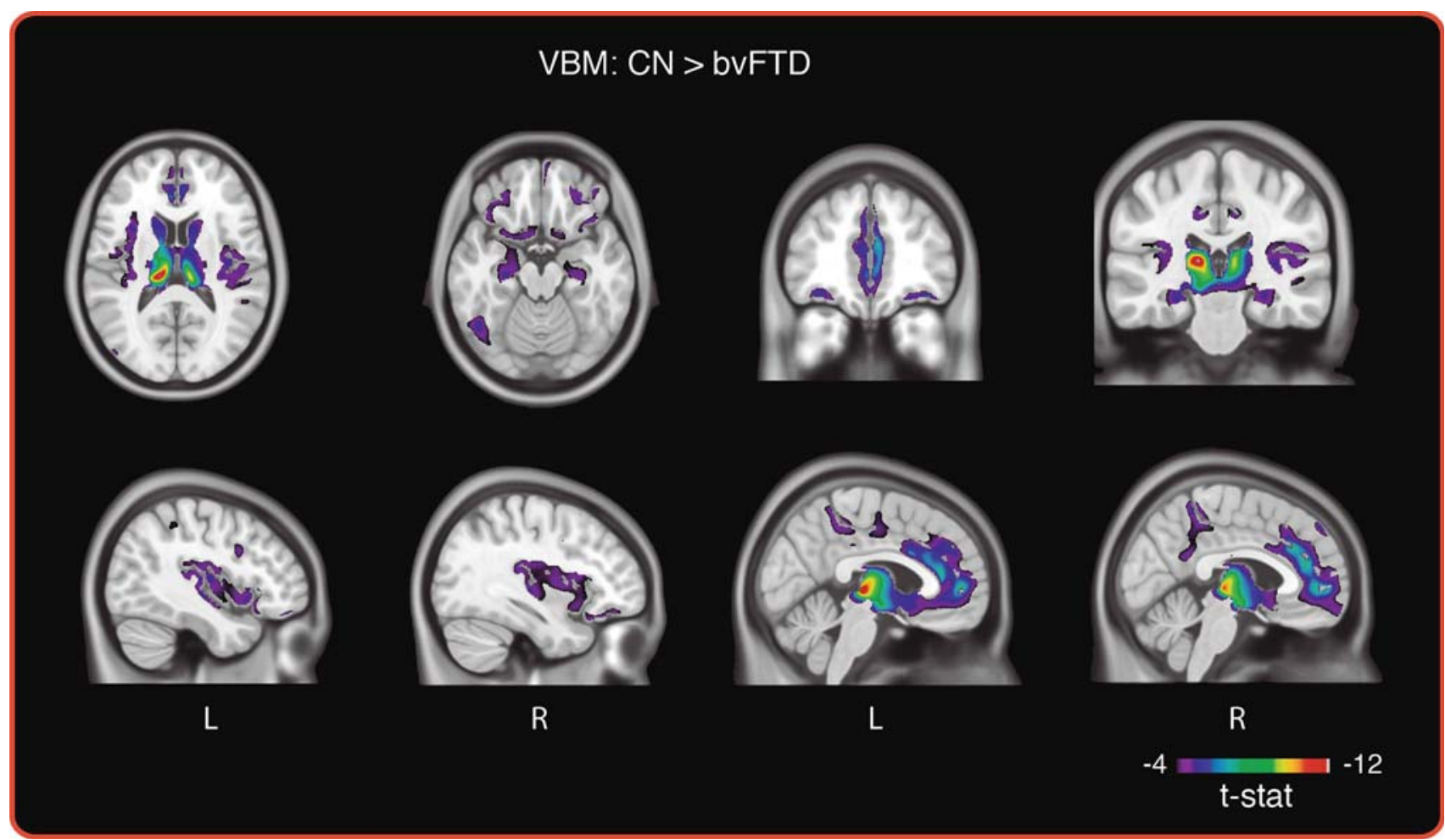

Fig. 4 Voxel-wise t-maps showing areas of reduced VBM derived GM concentration in patients with bvFTD compared with $\mathrm{CN}$ subjects $\left(88,845 \mathrm{~mm}^{3}\right.$; corrected for multiple comparisons, $\left.p<0.05\right)$. Atrophy was predominant in the thalami $(\mathrm{L}>\mathrm{R})$, head of caudate, insula,

\section{Discussion}

The present findings represent the first in vivo report of decreased availability of mGluR5 in bvFTD. In line with recent studies showing reduced binding of $\left[{ }^{11} \mathrm{C}\right] \mathrm{ABP} 688$ in disorders characterized by glutamate excitotoxicity-such as major depressive disorder and temporal lobe epilepsy (Choi et al. 2014; Deschwanden et al. 2011)—our findings may indicate altered glutamatergic neurotransmission in bvFTD, or conformational changes specific to the mGluR5 allosteric site. Further, we reproduced previous $\left[{ }^{18} \mathrm{~F}\right] \mathrm{FDG}$ and VBM findings in terms of both the topography of neurodegeneration and its partially asymmetric distribution (Diehl-Schmid et al. 2007; Hornberger et al. 2012; Jeong et al. 2005; Pan et al. 2012). In addition, we showed that the volume of decreased mGluR5 availability was inferior to that for hypometabolism and GM atrophy, and that the overlap between reduced $\left[{ }^{11} \mathrm{C}\right] \mathrm{ABP} 688 \mathrm{BP}_{\mathrm{ND}}$ and hypometabolism was superior to that for GM atrophy. Moreover, we showed that declines in mGluR5 availability were unique to several isocortical, limbic, and paralimbic areas, possibly representing an early sign of pyramidal cell dysfunction. In this respect, the focality of $\left[{ }^{11} \mathrm{C}\right] \mathrm{ABP} 688 \mathrm{BP}_{\mathrm{ND}}$ reductions in the present study is striking given the uncus/amygdala, and parahippocampus. GM loss was likewise noted in the putamen $(\mathrm{L}>\mathrm{R})$, precuneus $(\mathrm{R}>\mathrm{L})$, anterior cingulate $(\mathrm{L}>\mathrm{R})$, gyrus rectus, orbitofrontal gyrus and right superior/middle temporal gyri

widespread distribution of mGluR5. In addition, several frontotemporal areas showed hypometabolism and/or GM loss in the absence of reduced $\left[{ }^{11} \mathrm{C}\right] \mathrm{ABP} 688$ binding. Taken together, these findings suggest a differential neuronal vulnerability to FTLD pathology in bvFTD—similar to that seen in other neurodegenerative diseases (Double et al. 2010)—with reduced availability of mGluR5 possibly preceding neurodegeneration within select frontotemporal brain regions.

While at physiological concentrations glutamate is known to play a pivotal role in synaptic plasticity (Balschun et al. 2006; Huber et al. 2001)—with any given function of a given cortical region likely to depend on glutamatergic neurotransmission at some level (Francis 2009) - at high concentrations it has been shown to act as a neurotoxin, promoting neuronal injury and death in animal models (Rao et al. 2001; Rothstein 1996) and in neurodegenerative diseases, including AD (Francis 2003). In the case of $\mathrm{AD}$, accumulation of $\beta$-amyloid is thought to inhibit astroglial glutamate uptake, resulting in increased extracellular levels of glutamate, which, under chronic conditions, lead to cell death via sustained elevations in intracellular calcium (Harkany et al. 2000). This excitotoxic scenario may explain decreased binding of 


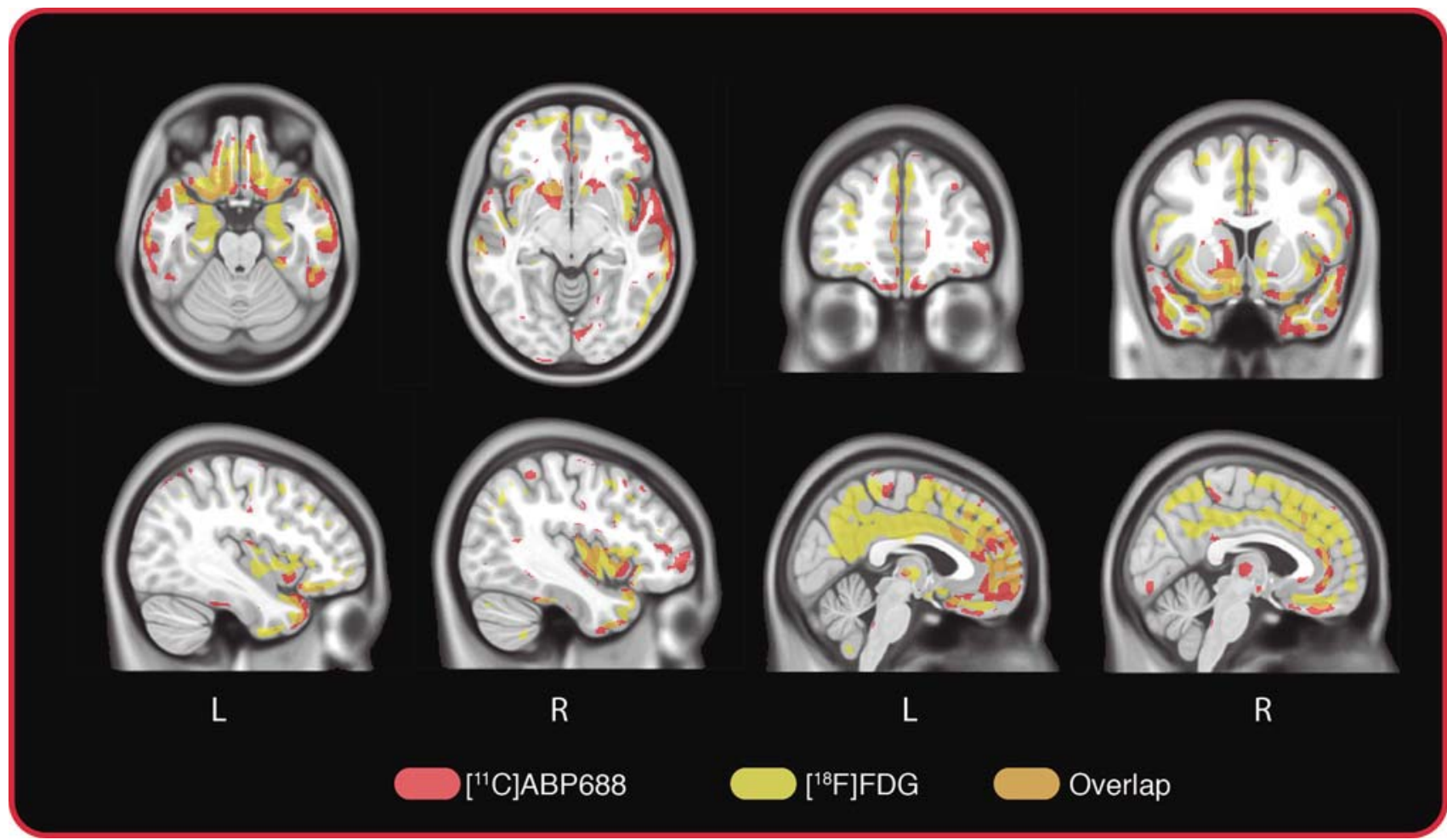

Fig. 5 Overlap (orange; 22,379 $\mathrm{mm}^{3}$ ) between binarized $\left[{ }^{11} \mathrm{C}\right] \mathrm{ABP} 688 \mathrm{BP}_{\mathrm{ND}}($ red $)$ and $\left[{ }^{18} \mathrm{~F}\right] \mathrm{FDG} \mathrm{SUV}_{\mathrm{R}}$ (yellow) t-maps was found with leftward predominance in the gyrus rectus, anterior cingulate dorso/ventromedial prefrontal cortex, and thalamus. Overlap was also noted with rightward asymmetry in the insula and in the temporal poles bilaterally

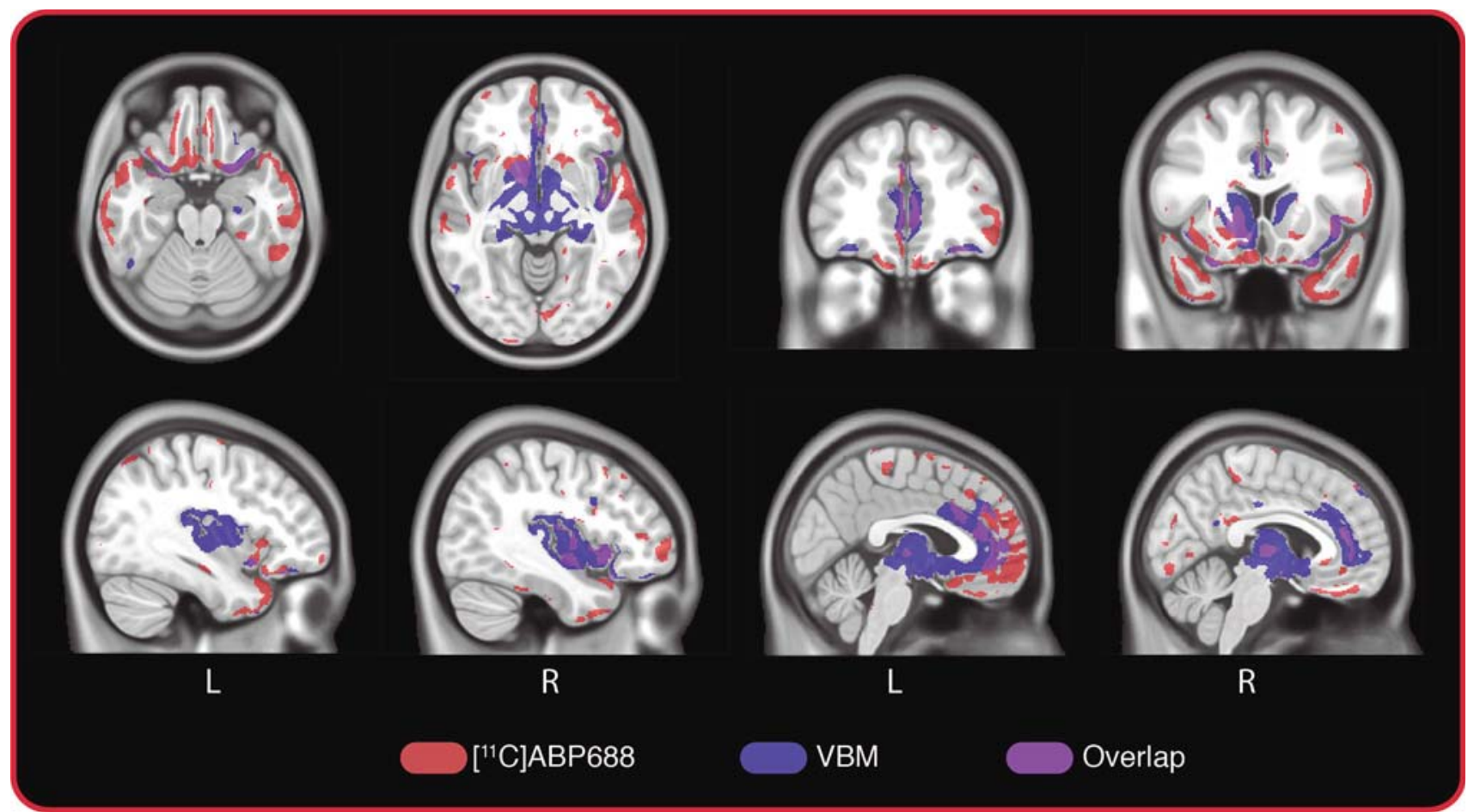

Fig. 6 Overlap (purple; 13,463 $\mathrm{mm}^{3}$ ) between binarized $\left[{ }^{11} \mathrm{C}\right] \mathrm{ABP} 688 \mathrm{BP}_{\mathrm{ND}}$ (red) and VBM (blue) t-maps was found with leftward asymmetry in the anterior cingulate, ventromedial prefrontal cortex, thalamus, and head of the caudate nucleus. Rightward asymmetry was noted in the insula and orbitofrontal cortex 


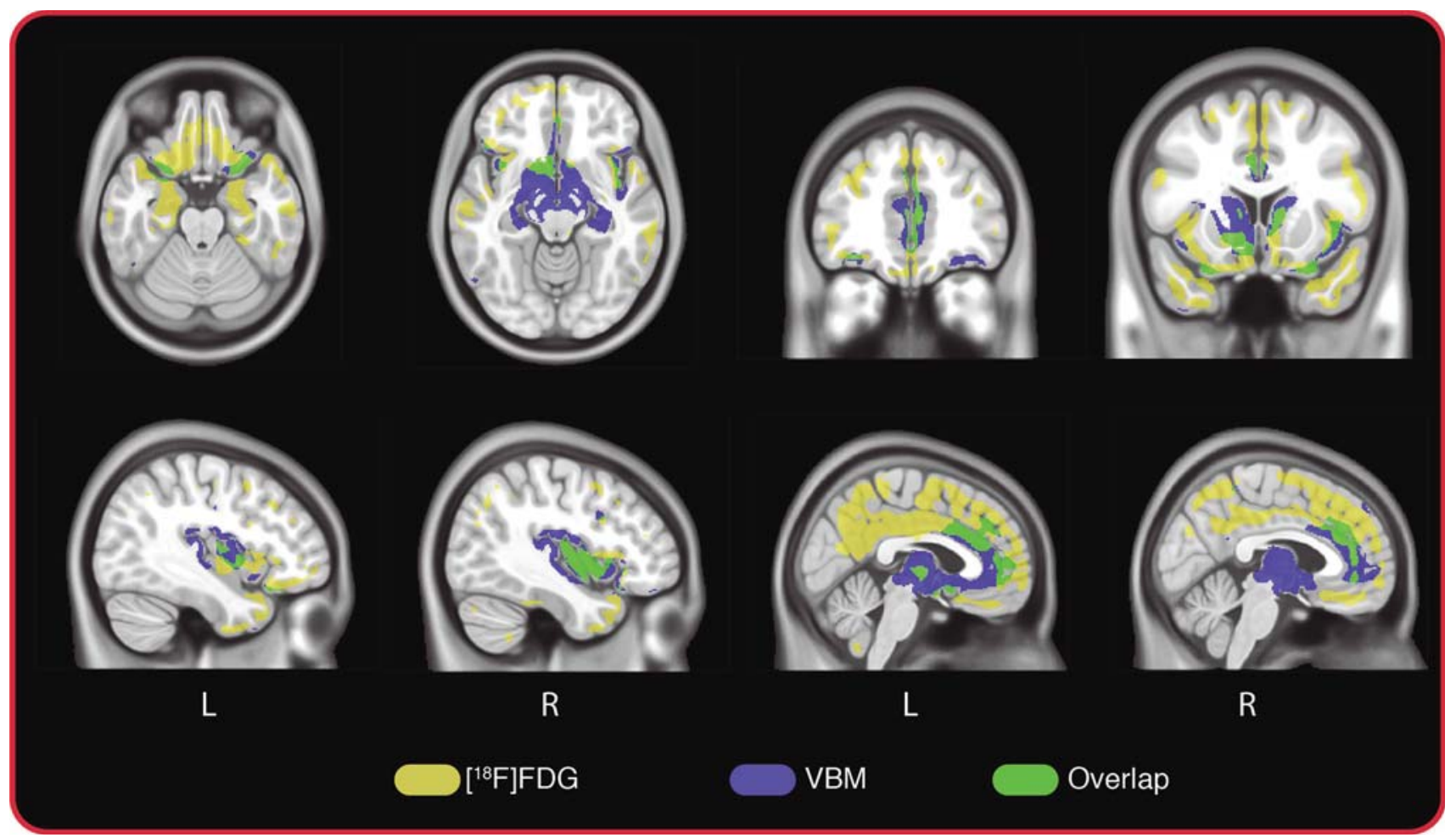

Fig. 7 Overlap (green; 14,179 $\mathrm{mm}^{3}$ ) between binarized $\left[{ }^{18} \mathrm{~F}\right] \mathrm{FDG}$ $\mathrm{SUV}_{\mathrm{R}}$ (red) and VBM (blue) t-maps was observed with leftward asymmetry in the orbitofrontal cortex, anterior cingulate/ventromedial prefrontal cortex, thalamus and amygdala. Rightward asymmetry was found in the dorsomedial prefrontal cortex, insula, hippocampal formation, and head of the caudate $\left[{ }^{11} \mathrm{C}\right] \mathrm{ABP} 688$ in that continued high levels of glutamate may alter the availability of its transmembrane allosteric binding site (Ametamey et al. 2007) by altering mGluR5 conformational states (Cabello et al. 2009; Canela et al. 2009; Changeux and Edelstein 2005; Romano et al. 1996). Indeed, affinity shifts in receptor-radioligand interactions have previously been described in the context of dopaminergic neurotransmission, where the affinity of a D2 PET radiopharmaceutical was altered following an amphetamine challenge (Narendran et al. 2004; Seneca et al. 2006; Wilson et al. 2005).

Recently, an expanded hexanucleotide repeat in the chromosome 9 open reading frame 72 (C9ORF72) was identified as the most common cause of familial FTD and amyotrophic lateral sclerosis (ALS), with mutations associated with deposition of TDP-43 pathology (DeJesusHernandez et al. 2011; Renton et al. 2011). While the pathogenic mechanism(s) by which this repeat expansion could cause disease remain unknown, induced pluripotent stem cell differentiated neurons from C9ORF72 ALS patients were shown to be highly susceptible to glutamate excitotoxicity (Donnelly et al. 2013). Related work on primary cells from TDP-43 transgenic mice showed an increased vulnerability to the toxic effects of excess glutamate (Swarup et al. 2011). Moreover, a recent study involving transgenic mice expressing the FTDP-17 mutation P301L in the human tau gene-resulting in the accumulation of hyperphosphorylated tau-showed a taudependent impairment of glutamate metabolism (Nilsen et al. 2013). These studies suggest that the pathogenicity of hyperphosphorylated tau and TDP-43-the molecular pathologies accounting for most cases of bvFTD (Mackenzie et al. 2011)-may involve glutamatergic excitotoxicity.

Certain methodological aspects, however, limit interpretation of the present findings. In addition to this study's cross-sectional design and small sample size, the absence of histopathological data precludes conclusions about the homogeneity of the sample from the perspective of underlying molecular pathology. As such we were not able to address the possible interplay between different FTLD subtypes and possibly differing effects on mGluR5 availability. Moreover, potential limitations may accompany the use of VBM when applied to atrophic brains (Good et al. 2002).

Despite these caveats, our findings shed light on the possible role of glutamate excitotoxicity in the pathogenesis of bvFTD and suggest that $\left[{ }^{11} \mathrm{C}\right] \mathrm{ABP} 688$ may prove a suitable non-invasive marker of glutamatergic neurotransmission in vivo. Larger prospective studies are required to 


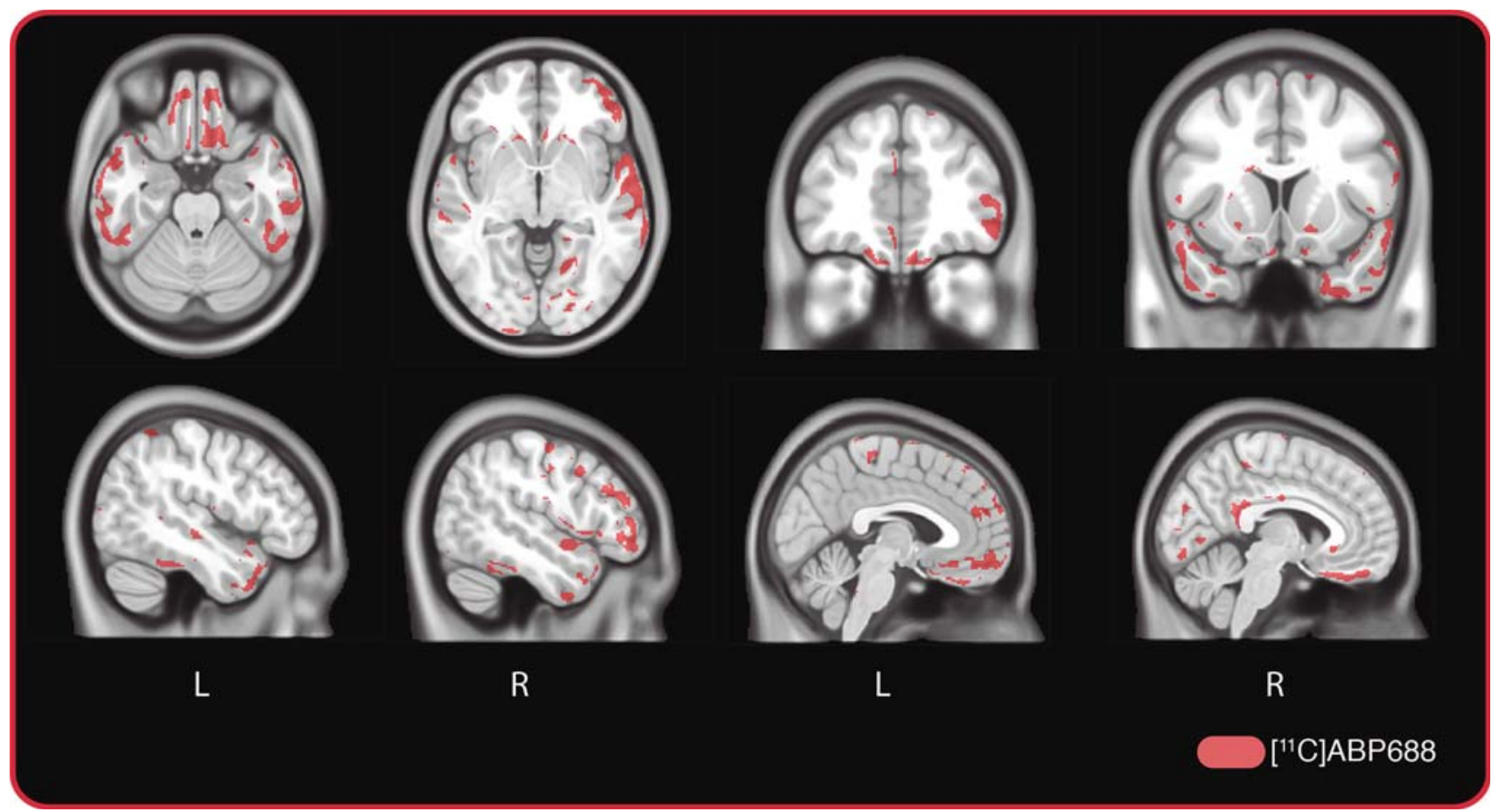

Fig. 8 Subtraction of binarized t-maps $\left(\left[{ }^{11} \mathrm{C}\right] \mathrm{ABP} 688 \mathrm{BP}_{\mathrm{ND}}-\right.$ $\left[{ }^{18} \mathrm{~F}\right] \mathrm{FDG} \mathrm{SUV} \mathrm{V}_{\mathrm{R}}-\mathrm{VBM}$ ) showed areas characterized only by declines in $\left[{ }^{11} \mathrm{C}\right] \mathrm{ABP} 688 \mathrm{BP}_{\mathrm{ND}}\left(55,742 \mathrm{~mm}^{3}\right)$. Areas characterized by rightward asymmetry included the inferior temporal lobes, temporal poles gyrus rectus, orbitofrontal cortex, head of the caudate nucleus, posterior cingulate, ventral/dorsolateral prefrontal cortex, lingual gyrus, and occipital cortex. Areas characterized by leftward asymmetry included the putamen, superior temporal lobe, and paracentral lobule

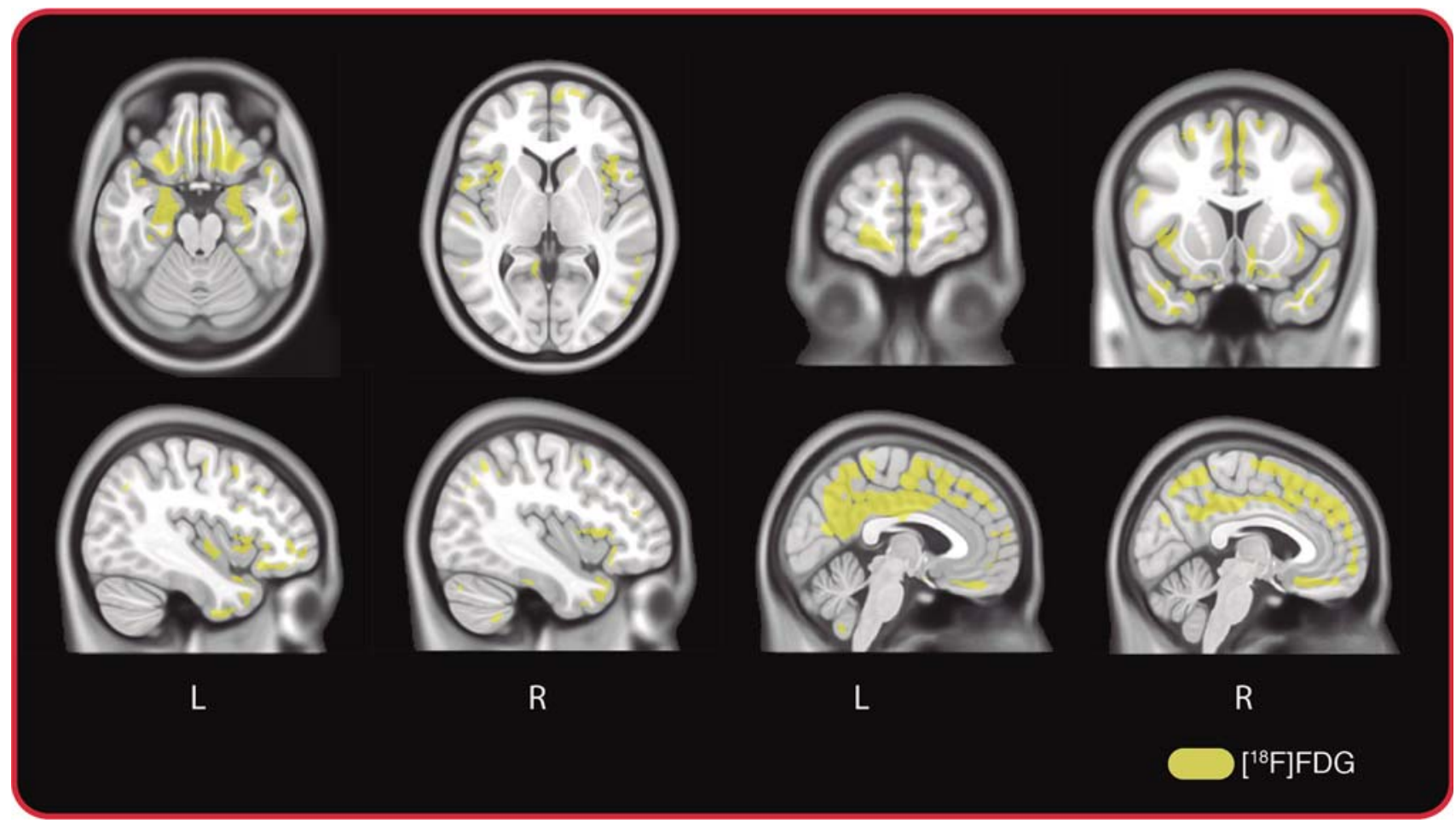

Fig. 9 Subtraction of binarized t-maps $\left(\left[{ }^{18} \mathrm{~F}\right] \mathrm{FDG} \quad \mathrm{SUV}_{\mathrm{R}}-\right.$ $\left.\left.{ }^{11} \mathrm{C}\right] \mathrm{ABP} 688 \mathrm{BP}_{\mathrm{ND}}-\mathrm{VBM}\right)$ showed areas characterized only by hypometabolism $\left(86,616 \mathrm{~mm}^{3}\right)$, including the bilateral insula, medial prefrontal cortex, left posterior paracentral lobule, left frontal operculum, anterior temporal poles, and bilateral cerebellar cortex. Leftward asymmetry was noted for the uncus/amygdalae, parahippocampus, and posterior cingulate/precuneus. Rightward asymmetry was noted for the orbitofrontal gyrus/gyrus rectus 


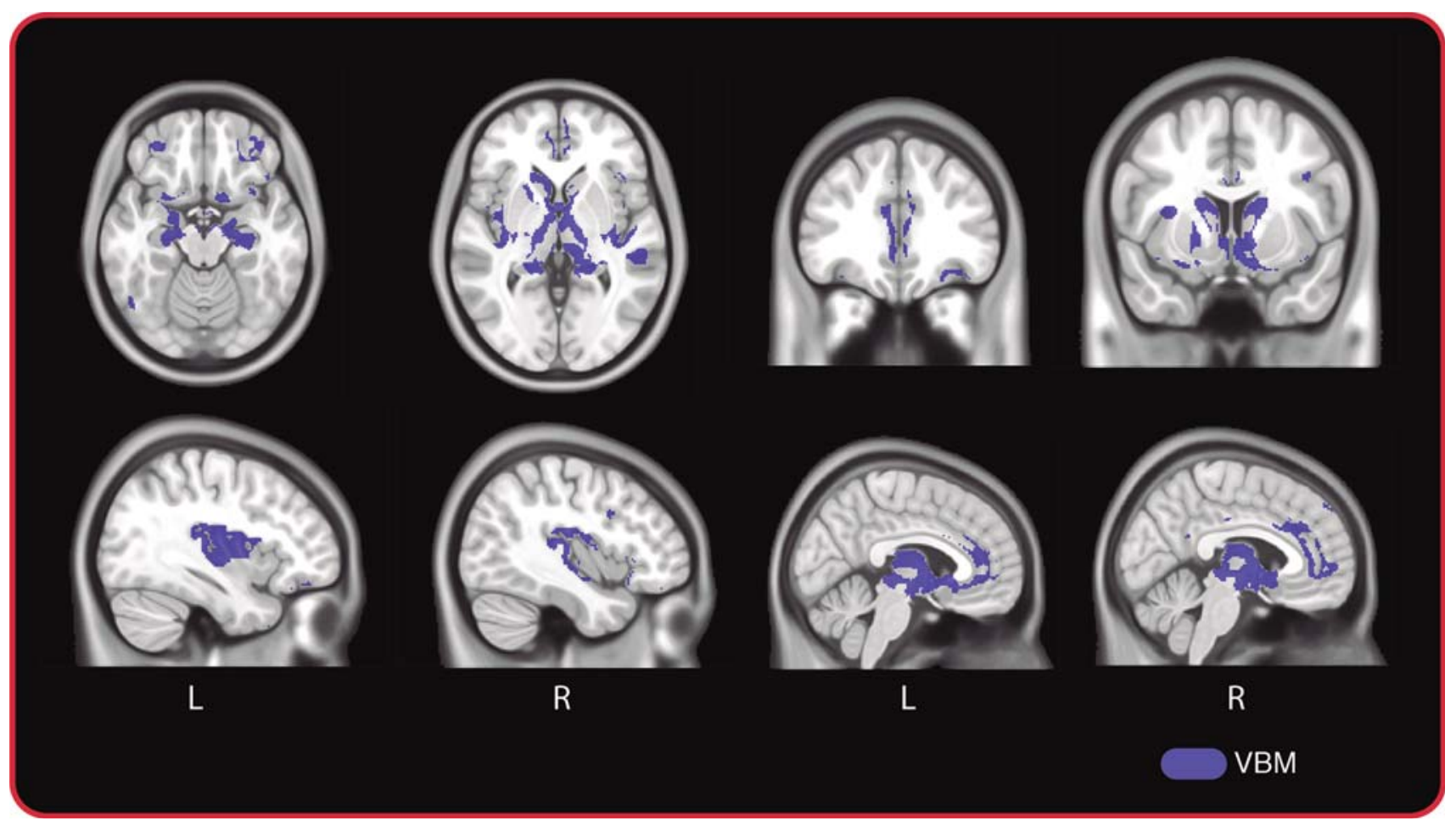

Fig. 10 Subtraction of binarized t-maps (VBM $-\left[{ }^{18} \mathrm{~F}\right] \mathrm{FDG}$ $\left.\mathrm{SUV}_{\mathrm{R}}-\left[{ }^{11} \mathrm{C}\right] \mathrm{ABP} 688 \mathrm{BP}_{\mathrm{ND}}\right)$ showed areas characterized only by reductions in $\mathrm{GM}\left(67,635 \mathrm{~mm}^{3}\right)$, including the orbitofrontal gyrus, the right middle temporal gyrus, right temporal operculum, left anterior insula, head of the caudate nucleus bilaterally, left posterior

validate these findings, to establish the trajectory of reduced mGluR5 availability relative to other biomarkers of neurodegeneration, and to address the potential link between the dysregulation of glutamatergic neurotransmission and bvFTD symptomatology.

Acknowledgments The authors wish to thank the patients and their families for participating in this study. This work was supported by the Canadian Institutes of Health Research (CIHR) [MOP-11-51-31], the Alan Tiffin Foundation, the Alzheimer's Association [NIRG-0892090], and the Fonds de la recherche en santé du Québec (Chercheur boursier). The authors wish to acknowledge the help of the imaging staff at the Montreal Neurological Institute McConnell Brain Imaging Centre, including Reda Bouhachi, Simion Matei, Rick Fukasawa (PET Technologists), Ron Lopez, David Costa, Louise Marcotte (MRI Technologists), and André Cormier (Chief MRI Technologist).

Conflict of interest The authors declare no conflict of interest.

\section{References}

Alladi S, Xuereb J, Bak T, Nestor P, Knibb J, Patterson K, Hodges JR (2007) Focal cortical presentations of Alzheimer's disease. Brain J Neurol 130:2636-2645. doi:10.1093/brain/awm213

Ametamey SM, Kessler LJ, Honer M, Wyss MT, Buck A, Hintermann S, Auberson YP, Gasparini F, Schubiger PA (2006) Radiosynthesis and preclinical evaluation of 11C-ABP688 as a inferior temporal gyrus, the thalamus as well as the posterior portion of the hippocampal formation, bilaterally. Leftward asymmetry was noted for the ventral amygdala, anterior cingulate gyrus, and putamina. Rightward asymmetry was noted for the posterior insula

probe for imaging the metabotropic glutamate receptor subtype 5. J Nucl Med 47:698-705

Ametamey SM, Treyer V, Streffer J, Wyss MT, Schmidt M, Blagoev M, Hintermann S, Auberson Y, Gasparini F, Fischer UC, Buck A (2007) Human PET studies of metabotropic glutamate receptor subtype 5 with 11C-ABP688. J Nucl Med 48:247-252

Ashburner J, Friston KJ (2000) Voxel-based morphometry-the methods. NeuroImage 11:805-821. doi:10.1006/nimg.2000.0582

Balschun D, Zuschratter W, Wetzel W (2006) Allosteric enhancement of metabotropic glutamate receptor 5 function promotes spatial memory. Neuroscience 142:691-702. doi:10.1016/j.neu roscience.2006.06.043

Cabello N, Gandía J, Bertarelli DC, Watanabe M, Lluís C, Franco R, Ferré S, Luján R, Ciruela F (2009) Metabotropic glutamate type 5, dopamine D2 and adenosine A2a receptors form higher-order oligomers in living cells. J Neurochem 109:1497-1507. doi:10. 1111/j.1471-4159.2009.06078.x

Canela L, Fernández-Dueñas V, Albergaria C, Watanabe M, Lluís C, Mallol J, Canela EI, Franco R, Luján R, Ciruela F (2009) The association of metabotropic glutamate receptor type 5 with the neuronal $\mathrm{Ca}^{2+}$-binding protein 2 modulates receptor function. J Neurochem 111:555-567. doi:10.1111/j.1471-4159.2009.06348.x

Changeux J-P, Edelstein SJ (2005) Allosteric mechanisms of signal transduction. Science 308:1424-1428. doi:10.1126/science. 1108595

Choi H, Kim YK, Oh SW, Im HJ, Hwang do W, Kang H, Lee B, Lee YS, Jeong JM, Kim EE, Chung JK, Lee DS (2014) In vivo imaging of mGluR5 changes during epileptogenesis using [11C]ABP688 PET in pilocarpine-induced epilepsy rat model. PLoS One 9:e92765. doi:10.1371/journal.pone.0092765 
Collins DL, Evans AC (1997) Animal: validation and applications of non-linear registration-based segmentation. Int J Pattern Recogn Art Intell 11:1271-1294

Collins DL, Zijendos AP, Barré WFC, Evans AC (1999) ANIMAL + INSECT: inproved cortical structure segmentation. In: Kuba A, Samal M, Todd-Pokropek A (eds) Lecture Notes in Computer Science. Springer-Verlag, Berlin, Heidelberg, pp 210-223

Comtat C, Sureau FC, Sibomana M, Hong IK, Sjoholm N, Trebossen $\mathrm{R}$ (2008) Image based resolution modeling for the HRRT OSEM reconstructions software. In: IEEE Nuclear Science Symposium Conference Record, pp 4120-4123

Costes N, Dagher A, Larcher K, Evans AC, Collins DL, Reilhac A (2009) Motion correction of multi-frame PET data in neuroreceptor mapping: simulation based validation. Neuroimage 47:1496-1505. doi:10.1016/j.neuroimage.2009.05.052

Cummings JL, Mega M, Gray K, Rosenberg-Thompson S, Carusi DA, Gornbein J (1994) The Neuropsychiatric Inventory: comprehensive assessment of psychopathology in dementia. Neurology 44:2308-2314

Dalfo E, Albasanz JL, Rodriguez A, Martin M, Ferrer I (2005) Abnormal group I metabotropic glutamate receptor expression and signaling in the frontal cortex in Pick disease. J Neuropathol Exp Neurol 64:638-647

DeJesus-Hernandez M, Mackenzie IR, Boeve BF, Boxer AL, Baker M, Rutherford NJ, Nicholson AM, Finch NA, Flynn H, Adamson J, Kouri N, Wojtas A, Sengdy P, Hsiung GY, Karydas A, Seeley WW, Josephs KA, Coppola G, Geschwind DH, Wszolek ZK, Feldman H, Knopman DS, Petersen RC, Miller BL, Dickson DW, Boylan KB, Graff-Radford NR, Rademakers R (2011) Expanded GGGGCC hexanucleotide repeat in noncoding region of C9ORF72 causes chromosome 9p-linked FTD and ALS. Neuron 72:245-256. doi:10.1016/j.neuron.2011.09.011

Deschwanden A, Karolewicz B, Feyissa AM, Treyer V, Ametamey SM, Johayem A, Burger C, Auberson YP, Sovago J, Stockmeier CA, Buck A, Hasler G (2011) Reduced metabotropic glutamate receptor 5 density in major depression determined by [(11)C]ABP688 PET and postmortem study. Am J Psychiatry 168:727-734. doi:10.1176/appi.ajp.2011.09111607

Diehl-Schmid J, Grimmer T, Drzezga A, Bornschein S, Riemenschneider M, Förstl H, Schwaiger M, Kurz A (2007) Decline of cerebral glucose metabolism in frontotemporal dementia: a longitudinal 18F-FDG-PET-study. Neurobiol Aging 28:42-50. doi:10.1016/j.neurobiolaging.2005.11.002

Donnelly CJ, Zhang PW, Pham JT, Haeusler AR, Mistry NA, Vidensky S, Daley EL, Poth EM, Hoover B, Fines DM, Maragakis N, Tienari PJ, Petrucelli L, Traynor BJ, Wang J, Rigo F, Bennett CF, Blackshaw S, Sattler R, Rothstein JD (2013) RNA toxicity from the ALS/FTD C9ORF72 expansion is mitigated by antisense intervention. Neuron 80:415-428. doi:10.1016/j.neuron.2013.10.015

Double KL, Reyes S, Werry EL, Halliday GM (2010) Selective cell death in neurodegeneration: why are some neurons spared in vulnerable regions? Prog Neurobiol 92:316-329. doi:10.1016/j. pneurobio.2010.06.001

Elmenhorst D, Biagini M, Minuzzi L, Aliaga A, Massarweh G, Diksic M, Avoli M, Bauer A, Rosa-Neto P (2009) Evaluation of reference models for [11C]ABP688 targeting the metabotropic glutamate receptor 5 in rats-application to an epilepsy model. J Cerebr Blood Flow Metab 29:S71-S72

Elmenhorst D, Minuzzi L, Aliaga A, Rowley J, Massarweh G, Diksic M, Bauer A, Rosa-Neto P (2010) In vivo and in vitro validation of reference tissue models for the $\operatorname{mGluR}(5)$ ligand [(11)C]ABP688. J Cereb Blood Flow Metab 30:1538-1549. doi:10.1038/jcbfm.2010.65
Ferraguti F, Shigemoto R (2006) Metabotropic glutamate receptors. Cell Tissue Res 326:483-504. doi:10.1007/s00441-006-0266-5

Ferrer I (1999) Neurons and their dendrites in frontotemporal dementia. Dement Geriatr Cogn Disord 10(Suppl 1):55-60. doi: $10.1159 / 000051214$

Folstein MF, Folstein SE, McHugh PR (1975) "Mini-mental state”. A practical method for grading the cognitive state of patients for the clinician. J Psychiatr Res 12:189-198

Fonov VS, Evans AC, McKinstry RC, Almli CR, Collins DL (2009) Unbiased nonlinear average age-appropriate brain templates from birth to adulthood. NeuroImage 47:S102. doi:10.1016/ S1053-8119(09)70884-5

Francis PT (2003) Glutamatergic systems in Alzheimer's disease. Int J Geriatr Psychiatry 18:S15-S21. doi:10.1002/gps.934

Francis PT (2009) Altered glutamate neurotransmission and behaviour in dementia: evidence from studies of memantine. Curr Mol Pharmacol 2:77-82

Goetz CG, Fahn S, Martinez-Martin P, Poewe W, Sampaio C, Stebbins GT, Stern MB, Tilley BC, Dodel R, Dubois B, Holloway R, Jankovic J, Kulisevsky J, Lang AE, Lees A, Leurgans S, LeWitt PA, Nyenhuis D, Olanow CW, Rascol O, Schrag A, Teresi JA, Van Hilten JJ, LaPelle N (2007) Movement Disorder Society-sponsored revision of the Unified Parkinson's Disease Rating Scale (MDS-UPDRS): process, format, and clinimetric testing plan. Mov Disord 22:41-47. doi:10.1002/mds. 21198

Good CD, Scahill RI, Fox NC, Ashburner J, Friston KJ, Chan D, Crum WR, Rossor MN, Frackowiak RS (2002) Automatic differentiation of anatomical patterns in the human brain: validation with studies of degenerative dementias. Neuroimage 17:29-46

Greve DN, Svarer C, Fisher PM, Feng L, Hansen AE, Baare W, Rosen B, Fischl B, Knudsen GM (2014) Cortical surface-based analysis reduces bias and variance in kinetic modeling of brain PET data. Neuroimage 92:225-236. doi:10.1016/j.neuroimage. 2013.12.021

Gunn RN, Lammertsma AA, Hume SP, Cunningham VJ (1997) Parametric imaging of ligand-receptor binding in PET using a simplified reference region model. Neuroimage 6:279-287. doi:10.1006/nimg.1997.0303

Harkany T, Abrahám I, Timmerman W, Laskay G, Tóth B, Sasvári M, Kónya C, Sebens JB, Korf J, Nyakas C, Zarándi M, Soós K, Penke B, Luiten PG (2000) beta-amyloid neurotoxicity is mediated by a glutamate-triggered excitotoxic cascade in rat nucleus basalis. Eur J Neurosci 12:2735-2745

Hornberger M, Wong S, Tan R, Irish M, Piguet O, Kril J, Hodges JR, Halliday G (2012) In vivo and post-mortem memory circuit integrity in frontotemporal dementia and Alzheimer's disease. Brain 135:3015-3025. doi:10.1093/brain/aws239

Huber KM, Roder JC, Bear MF (2001) Chemical induction of mGluR5- and protein synthesis-dependent long-term depression in hippocampal area CA1. J Neurophysiol 86:321-325

Jeong Y, Cho SS, Park JM, Kang SJ, Lee JS, Kang E, Na DL, Kim SE (2005) 18F-FDG PET findings in frontotemporal dementia: an SPM analysis of 29 patients. J Nucl Med 46:233-239

Kertesz A, Davidson W, Fox H (1997) Frontal behavioral inventory: diagnostic criteria for frontal lobe dementia. Can J Neurol Sci 24:29-36

Kipps CM, Davies RR, Mitchell J, Kril JJ, Halliday GM, Hodges JR (2007) Clinical significance of lobar atrophy in frontotemporal dementia: application of an MRI visual rating scale. Dement Geriatr Cogn Disord 23:334-342. doi:10.1159/000100973

Lerch J (2006) Voxel-wise morphometry using RMINC. http://www. bic.mni.mcgill.ca/ samir/Brain_imaging/RMINC.pdf. Accessed 15 July 2014 
Llansola M, Felipo V (2010) Metabotropic glutamate receptor 5, but not 1, modulates NMDA receptor-mediated activation of neuronal nitric oxide synthase. Neurochem Int 56:535-545. doi:10. 1016/j.neuint.2009.12.016

Mackenzie IR, Neumann M, Bigio EH, Cairns NJ, Alafuzoff I, Kril J, Kovacs GG, Ghetti B, Halliday G, Holm IE, Ince PG, Kamphorst W, Revesz T, Rozemuller AJ, Kumar-Singh S, Akiyama H, Baborie A, Spina S, Dickson DW, Trojanowski JQ, Mann DM (2010) Nomenclature and nosology for neuropathologic subtypes of frontotemporal lobar degeneration: an update. Acta Neuropathol 119:1-4. doi:10.1007/s00401-009-0612-2

Mackenzie IR, Munoz DG, Kusaka H, Yokota O, Ishihara K, Roeber S, Kretzschmar HA, Cairns NJ, Neumann M (2011) Distinct pathological subtypes of FTLD-FUS. Acta Neuropathol 121:207-218. doi:10.1007/s00401-010-0764-0

McCrimmon AW, Smith AD (2013) Test Review: review of the Wechsler Abbreviated Scale of Intelligence, Second Edition (WASI-II). J Psychoeduc Assess 31:337-341. doi:10.1177/ 0734282912467756

Mendez MF, Lauterbach EC, Sampson SM, ANPA Committee on Research (2008) An evidence-based review of the psychopathology of frontotemporal dementia: a report of the ANPA Committee on Research. J Neuropsychiatry Clin Neurosci 20:130-149. doi:10.1176/appi.neuropsych.20.2.130

Minuzzi L, Diksic M, Gauthier S, Quirion R, Rosa-Neto P (2009) In vitro quantification of mGluR5 in pons and cerebellum of human brain using [H-3]ABP688. J Cerebr Blood F Met 29:S368-S369

Muller-Gartner HW, Links JM, Prince JL, Bryan RN, McVeigh E, Leal JP, Davatzikos C, Frost JJ (1992) Measurement of radiotracer concentration in brain gray matter using positron emission tomography: MRI-based correction for partial volume effects. J Cereb Blood Flow Metab 12:571-583. doi:10.1038/ jcbfm. 1992.81

Narendran R, Hwang DR, Slifstein M, Talbot PS, Erritzoe D, Huang $\mathrm{Y}$ (2004) In vivo vulnerability to competition by dopamine: comparison of the D2 receptor agonist radiotracer (-)- $\mathrm{N}$ [11C]propyl-norapomorphine ([11C]NPA) with the D2 receptor antagonist radiotracer [11C]-racloprid. Synapse 52:188-208. doi:10.1002/syn.20013

Natarajan MK, Paul N, Mercuri M, Waller EJ, Leipsic J, Traboulsi M, Banijamali HS, Benson L, Sheth TN, Secondary Panel: Simpson CS, Brydie A, Love MP, Gallo R, Canadian Cardiovascular Society (2013) Canadian Cardiovascular Society position statement on radiation exposure from cardiac imaging and interventional procedures. Can J Cardiol 29:1361-1368. doi:10.1016/j. cjca.2013.06.002

Nilsen LH, Rae C, Ittner LM, Gotz J, Sonnewald U (2013) Glutamate metabolism is impaired in transgenic mice with tau hyperphosphorylation. J Cereb Blood Flow Metab 33:684-691. doi:10. 1038/jcbfm.2012.212

Niswender CM, Conn PJ (2010) Metabotropic glutamate receptors: physiology, pharmacology, and disease. Annu Rev Pharmacol Toxicol 50:295-322. doi:10.1146/annurev.pharmtox.011008. 145533

Pan PL, Song W, Yang J, Huang R, Chen K, Gong QY, Zhong JG, Shi HC, Shang HF (2012) Gray matter atrophy in behavioral variant frontotemporal dementia: a meta-analysis of voxel-based morphometry studies. Dement Geriatr Cogn Disord 33:141-148. doi:10.1159/000338176

Perroy J, Raynaud F, Homburger V, Rousset MC, Telley L, Bockaert J, Fagni L (2008) Direct interaction enables cross-talk between ionotropic and group I metabotropic glutamate receptors. J Biol Chem 283:6799-6805. doi:10.1074/jbc.M705661200

Poljansky S, Ibach B, Hirschberger B, Manner P, Klunemann H, Hajak G, Marienhagen J (2011) A visual [18F]FDG-PET rating scale for the differential diagnosis of frontotemporal lobar degeneration. Eur Arch Psychiatry Clin Neurosci 261:433-446. doi:10.1007/s00406-010-0184-0

Procter AW, Qurne M, Francis PT (1999) Neurochemical features of frontotemporal dementia. Dement Geriatr Cogn Disord 10(Suppl 1):80-84. doi:10.1159/000051219

Quarantelli M, Berkouk K, Prinster A, Landeau B, Svarer C, Balkay L, Alfano B, Brunetti A, Baron JC, Salvatore M (2004) Integrated software for the analysis of brain PET/SPECT studies with partial-volume-effect correction. J Nucl Med 45:192-201

Rao VL, Bowen KK, Dempsey RJ (2001) Transient focal cerebral ischemia down-regulates glutamate transporters GLT-1 and EAAC1 expression in rat brain. Neurochem Res 26:497-502

Rascovsky K, Hodges JR, Knopman D, Mendez MF, Kramer JH, Neuhaus J, van Swieten JC, Seelaar H, Dopper EG, Onyike CU, Hillis AE, Josephs KA, Boeve BF, Kertesz A, Seeley WW, Rankin KP, Johnson JK, Gorno-Tempini ML, Rosen H, PrioleauLatham CE, Lee A, Kipps CM, Lillo P, Piguet O, Rohrer JD, Rossor MN, Warren JD, Fox NC, Galasko D, Salmon DP, Black SE, Mesulam M, Weintraub S, Dickerson BC, Diehl-Schmid J, Pasquier F, Deramecourt V, Lebert F, Pijnenburg Y, Chow TW, Manes F, Grafman J, Cappa SF, Freedman M, Grossman M, Miller BL (2011) Sensitivity of revised diagnostic criteria for the behavioural variant of frontotemporal dementia. Brain 134:2456-2477. doi:10.1093/brain/awr179

Ratnavalli E, Brayne C, Dawson K, Hodges JR (2002) The prevalence of frontotemporal dementia. Neurology 58:1615-1621

Renton AE, Majounie E, Waite A, Simón-Sánchez J, Rollinson S, Gibbs JR, Schymick JC, Laaksovirta H, van Swieten JC, Myllykangas L, Kalimo H, Paetau A, Abramzon Y, Remes AM, Kaganovich A, Scholz SW, Duckworth J, Ding J, Harmer DW, Hernandez DG, Johnson JO, Mok K, Ryten M, Trabzuni D, Guerreiro RJ, Orrell RW, Neal J, Murray A, Pearson J, Jansen IE, Sondervan D, Seelaar H, Blake D, Young K, Halliwell N, Callister JB, Toulson G, Richardson A, Gerhard A, Snowden J, Mann D, Neary D, Nalls MA, Peuralinna T, Jansson L, Isoviita VM, Kaivorinne AL, Hölttä-Vuori M, Ikonen E, Sulkava R, Benatar M, Wuu J, Chiò A, Restagno G, Borghero G, Sabatelli M, ITALSGEN Consortium, Heckerman D, Rogaeva E, Zinman L, Rothstein JD, Sendtner M, Drepper C, Eichler EE, Alkan C, Abdullaev Z, Pack SD, Dutra A, Pak E, Hardy J, Singleton A, Williams NM, Heutink P, Pickering-Brown S, Morris HR, Tienari PJ, Traynor BJ (2011) A hexanucleotide repeat expansion in C9ORF72 is the cause of chromosome 9p21-linked ALSFTD. Neuron 72:257-268. doi:10.1016/j.neuron.2011.09.010

Roman GC, Tatemichi TK, Erkinjuntti T, Cummings JL, Masdeu JC, Garcia JH, Amaducci L, Orgogozo JM, Brun A, Hofman A, Moody DM, O'Brien MD, Yamaguchi T, Grafman J, Drayer BP, Bennett DA, Fisher M, Ogata J, Kokmen E, Bermejo F, Wolf PA, Gorelick PB, Bick KL, Pajeau AK, Bell MA, DeCarli C, Culebras A, Korczyn AD, Bogousslavsky J, Hartmann A, Scheinberg P (1993) Vascular dementia: diagnostic criteria for research studies. Report of the NINDS-AIREN International Workshop. Neurology 43:250-260

Romano C, Yang WL, O’Malley KL (1996) Metabotropic glutamate receptor 5 is a disulfide-linked dimer. J Biol Chem 271:28612-28616

Rothstein JD (1996) Excitotoxicity hypothesis. Neurology 47:S19S26

Rousset OG, Ma Y, Evans AC (1998) Correction for partial volume effects in PET: principle and validation. J Nucl Med 39:904-911

Rousset O, Rahmim A, Alavi A, Zaidi H (2007) Partial volume correction strategies in PET. PET Clin 2:235-249

Rosso SM, Donker Kaat L, Baks T, Joosse M, de Koning I, Pijnenburg Y, de Jong D, Dooijes D, Kamphorst W, Ravid R, Niermeijer MF, Verheij F, Kremer HP, Scheltens P, van Duijn 
CM, Heutink P, van Swieten JC (2003) Frontotemporal dementia in The Netherlands: patient characteristics and prevalence estimates from a population-based study. Brain 126:2016-2022. doi:10.1093/brain/awg204

Schaeffer E, Duplantier A (2010) Glutamate and Neurodegenerative Disease. In: Dominguez C (ed) Neurodegenerative Diseases. Springer-Verlag, Berlin, Heidelberg, pp 91-147

Seneca N, Finnema SJ, Farde L, Gulyas B, Wikstrom HV, Halldin C, Innis RB (2006) Effect of amphetamine on dopamine D2 receptor binding in nonhuman primate brain: a comparison of the agonist radioligand [11C]MNPA and antagonist [11C]raclopride. Synapse 59:260-269. doi:10.1002/syn.20238

Sled JGZA, Evans AC (1998) A nonparametric method for automatic correction of intensity nonuniformity in MRI data. IEEE Trans Med Imaging 17:87-97

Swartz JR, Miller BL, Lesser IM, Booth R, Darby A, Wohl M, Benson DF (1997) Behavioral phenomenology in Alzheimer's disease, frontotemporal dementia, and late-life depression: a retrospective analysis. J Geriatr Psychiatry Neurol 10:67-74
Swarup V, Phaneuf D, Dupre N, Petri S, Strong M, Kriz J, Julien JP (2011) Deregulation of TDP-43 in amyotrophic lateral sclerosis triggers nuclear factor kappaB-mediated pathogenic pathways. J Exp Med 208:2429-2447. doi:10.1084/jem.20111313

Wilson AA, McCormick P, Kapur S, Willeit M, Garcia A, Hussey D, Houle S, Seeman P, Ginovart N (2005) Radiosynthesis and evaluation of [11C]-(+)-4-propyl-3,4,4a,5,6,10b-hexahydro-2Hnaphtho[1,2-b][1,4] oxazin-9-ol as a potential radiotracer for in vivo imaging of the dopamine D2 high-affinity state with positron emission tomography. J Med Chem 48:4153-4160. doi:10.1021/jm050155n

Worsley KJ, Cao J, Paus T, Petrides M, Evans AC (1998) Applications of random field theory to functional connectivity. Hum Brain Mapp 6:364-367

Zijdenbos AFR, Evans AC (1998) Automatic quantification of MS lesions in 3D MRI brain data sets: validation of INSECT. In: Wells M, Colchester A, Delp S (eds) Lecture Notes in Computer Science. Springer, Berlin, Heidelberg, New York, pp 438-448 